\title{
A global wetland methane emissions and uncertainty dataset for atmospheric chemical transport models (WetCHARTs version 1.0)
}

\author{
A. Anthony Bloom ${ }^{1}$, Kevin W. Bowman ${ }^{1}$, Meemong Lee ${ }^{1}$, Alexander J. Turner ${ }^{2}$, Ronny Schroeder ${ }^{3}$, John R. Worden ${ }^{1}$, \\ Richard Weidner ${ }^{1}$, Kyle C. McDonald ${ }^{1,3}$, and Daniel J. Jacob ${ }^{2}$ \\ ${ }^{1}$ Jet Propulsion Laboratory, California Institute of Technology, Pasadena, CA, USA \\ ${ }^{2}$ School of Engineering and Applied Sciences, Harvard University, Cambridge, MA, USA \\ ${ }^{3}$ The City College of New York, New York, NY, USA \\ Correspondence to: A. Anthony Bloom (abloom@jpl.nasa.gov)
}

Received: 23 August 2016 - Discussion started: 7 September 2016

Revised: 13 April 2017 - Accepted: 24 April 2017 - Published: 6 June 2017

\begin{abstract}
Wetland emissions remain one of the principal sources of uncertainty in the global atmospheric methane $\left(\mathrm{CH}_{4}\right)$ budget, largely due to poorly constrained process controls on $\mathrm{CH}_{4}$ production in waterlogged soils. Process-based estimates of global wetland $\mathrm{CH}_{4}$ emissions and their associated uncertainties can provide crucial prior information for model-based top-down $\mathrm{CH}_{4}$ emission estimates. Here we construct a global wetland $\mathrm{CH}_{4}$ emission model ensemble for use in atmospheric chemical transport models (WetCHARTs version 1.0). Our $0.5^{\circ} \times 0.5^{\circ}$ resolution model ensemble is based on satellite-derived surface water extent and precipitation reanalyses, nine heterotrophic respiration simulations (eight carbon cycle models and a data-constrained terrestrial carbon cycle analysis) and three temperature dependence parameterizations for the period 2009-2010; an extended ensemble subset based solely on precipitation and the data-constrained terrestrial carbon cycle analysis is derived for the period 2001-2015. We incorporate the mean of the full and extended model ensembles into GEOS-Chem and compare the model against surface measurements of atmospheric $\mathrm{CH}_{4}$; the model performance (site-level and zonal mean anomaly residuals) compares favourably against published wetland $\mathrm{CH}_{4}$ emissions scenarios. We find that uncertainties in carbon decomposition rates and the wetland extent together account for more than $80 \%$ of the dominant uncertainty in the timing, magnitude and seasonal variability in wetland $\mathrm{CH}_{4}$ emissions, although uncertainty in the temperature $\mathrm{CH}_{4}: \mathrm{C}$ dependence is a significant contributor to seasonal variations in mid-latitude wetland $\mathrm{CH}_{4}$ emissions. The combination of satellite, carbon cycle models and tem-
\end{abstract}

perature dependence parameterizations provides a physically informed structural a priori uncertainty that is critical for topdown estimates of wetland $\mathrm{CH}_{4}$ fluxes. Specifically, our ensemble can provide enhanced information on the prior $\mathrm{CH}_{4}$ emission uncertainty and the error covariance structure, as well as a means for using posterior flux estimates and their uncertainties to quantitatively constrain the biogeochemical process controls of global wetland $\mathrm{CH}_{4}$ emissions.

\section{Introduction}

Methane $\left(\mathrm{CH}_{4}\right)$ is a potent greenhouse gas with a global warming potential more than 25 times that of $\mathrm{CO}_{2}$ on a 100 year time horizon (Myhre et al., 2013). The global $\mathrm{CH}_{4}$ budget and growth rate remain poorly understood, largely due to the poorly resolved evolution of atmospheric $\mathrm{CH}_{4}$ sources and sinks (Nisbet et al., 2014). Wetland $\mathrm{CH}_{4}$ emissions are the largest natural source of atmospheric $\mathrm{CH}_{4}$, amounting to roughly $20-40 \%$ of global $\mathrm{CH}_{4}$ emissions (Ciais et al., 2013). The large disparities between a range of top-down and bottom-up wetland $\mathrm{CH}_{4}$ estimates (Kirschke et al., 2013; Melton et al., 2013) arise from large uncertainties in the timing, distribution and the underlying processes controlling net wetland $\mathrm{CH}_{4}$ production.

In wetland soils, $\mathrm{CH}_{4}$ is produced through the decomposition of organic matter in anaerobic (oxygen-depleted) environments. The dominant processes controlling the seasonal and inter-annual variations include the carbon availability (soil $\mathrm{C}$ substrate) and decomposition rate, wetland 
inundation extent and temperature (Yvon-Durocher et al., 2014). Other important controls on wetland $\mathrm{CH}_{4}$ emissions include the presence of macrophytes (Laanbroek, 2010), organic C decomposition rates (Miyajima et al., 1997) and soil pH (Singh et al., 2000), amongst other factors. The link between terrestrial carbon-water cycling and wetland $\mathrm{CH}_{4}$ emissions is of particular interest from a terrestrial greenhouse gas emissions standpoint: inter-annual variations in terrestrial carbon cycling (Le Quéré et al., 2013) can affect wetland $\mathrm{CH}_{4}$ emissions on seasonal to century timescales (Hodson et al., 2011). The role of carbon cycle dynamics in global wetland $\mathrm{CH}_{4}$ emissions is increasingly recognized. Temporal variations in gross primary production influence the short-term carbon supply (such as carbon inputs from root exudates and fine litter) as well as long-lived carbon stores (such as wood litter turnover or soil organic C) in wetland soils (Riley et al., 2011; Bloom et al., 2012; Melton et al., 2013). The combined response of $\mathrm{CO}_{2}$ and $\mathrm{CH}_{4}$ fluxes to climatic variability remains poorly characterized. For example, increasing temperatures in boreal ecosystems could lead to higher carbon uptake, increased respiration and drier soils (Watts et al., 2014), and it is currently unclear whether these processes amount to an amplifying or a dampening effect on boreal $\mathrm{CH}_{4}$ emissions. From a greenhouse gas balance standpoint, quantifying the global-scale process links between terrestrial carbon cycling and wetland $\mathrm{CH}_{4}$ emissions is crucial to characterizing the combined terrestrial biosphere $\mathrm{CO}_{2}$ and $\mathrm{CH}_{4}$ flux response to climatic variability.

The quantification of regional wetland $\mathrm{CH}_{4}$ emissions remains challenging. While wetland $\mathrm{CH}_{4}$ emissions are relatively well constrained on a global scale (Kirschke et al., 2013; Saunois et al., 2016), regional $\mathrm{CH}_{4}$ fluxes are difficult to detect due to their comparatively diffuse nature relative to anthropogenic point sources and the scarcity of direct measurements of wetland $\mathrm{CH}_{4}$ emissions. From a bottomup perspective, challenges in wetland $\mathrm{CH}_{4}$ modelling stem from order-of-magnitude uncertainties in wetland $\mathrm{CH}_{4}$ emission factors and their spatio-temporal dependence on biogeochemical process controls. Nonetheless, for top-down $\mathrm{CH}_{4}$ emission estimates, prior knowledge of wetland $\mathrm{CH}_{4}$ emissions and their associated uncertainty is critical in the formulation of Bayesian atmospheric $\mathrm{CH}_{4}$ inversions. Atmospheric inversions combine $\mathrm{CH}_{4}$ measurements from surface, aircraft and satellites (Wecht et al., 2014a; Jacob et al., 2016) and the prior probability of the magnitude and uncertainty characteristics of $\mathrm{CH}_{4}$ emissions (Bousquet et al., 2011; Pison et al., 2013; Fraser et al., 2013; Turner et al., 2015). Typically, $\mathrm{CH}_{4}$ inversions do not explicitly formulate wetland $\mathrm{CH}_{4}$ emission uncertainty correlations; rather, prior wetland $\mathrm{CH}_{4}$ uncertainty correlations are either absent or implicitly prescribed through space-time correlation lengths on $\mathrm{CH}_{4}$ emissions. However, inter-model similarities reveal significant levels of emergent correlations in the timing, magnitude and spatial variability of wetland $\mathrm{CH}_{4}$ emissions. For example, the Wetland $\mathrm{CH}_{4}$ Inter-comparison of Models Project
(WETCHIMP) model ensemble (Melton et al., 2013) reveals varying levels of spatial and temporal agreement between models; these correlations stem from large-scale patterns in biogeochemical process controls (such as temperature, inundation and carbon cycling). Given the relatively large WETCHIMP $\mathrm{CH}_{4}$ emission uncertainties (the model range is typically $150-300 \%$ of the model mean over major wetland areas and greater elsewhere), this prior "biogeochemical covariance" can potentially amount to a critical constraint on atmospheric $\mathrm{CH}_{4}$ inversions; such a covariance structure can be incorporated into an atmospheric inversion cost function (Michalak et al., 2005) or as a means of improving the attribution of posterior $\mathrm{CH}_{4}$ fluxes to wetland $\mathrm{CH}_{4}$ emissions (Wecht et al., 2014b).

Here we propose a process-informed wetland $\mathrm{CH}_{4}$ emission and uncertainty dataset for atmospheric chemistry and transport modelling (WetCHARTs) based on multiple terrestrial biosphere models, wetland extent scenarios and $\mathrm{CH}_{4}: \mathrm{C}$ temperature dependencies. In contrast to a conventional process-based model inter-comparison approach, our wetland $\mathrm{CH}_{4}$ emission ensemble members are derived by exhaustively combining a range of temperature, carbon and wetland extent parameterizations. An advantage of our approach is that it provides a prior probability distribution of biogeochemical process control uncertainty. Top-down $\mathrm{CH}_{4}$ emission estimates can then be used to quantify (a) the probability of individual ensemble members and (b) the combined probability distribution of carbon models, $\mathrm{CH}_{4}: \mathrm{C}$ temperature dependencies and wetland extent scenarios.

We formulate a full (2009-2010) and extended (20012015) estimate of wetland $\mathrm{CH}_{4}$ emission magnitude and its associated biogeochemical covariance structure, based on knowledge of the global wetland $\mathrm{CH}_{4}$ source and the primary biogeochemical process controls. We validate and compare the wetland $\mathrm{CH}_{4}$ emissions ensemble against a suite of regional flux estimates; we use a global atmospheric chemical transport model (GEOS-Chem; Bey et al., 2001) to evaluate the $\mathrm{CH}_{4}$ emissions ensemble mean relative to existing wetland $\mathrm{CH}_{4}$ emission models (Sects. 2 and 3). Finally, we summarize the strengths and limitations of our wetland emissions ensemble and outline its potential applications in global atmospheric inversion frameworks (Sect. 4).

\section{Wetland $\mathrm{CH}_{4}$ model ensemble}

The wetland $\mathrm{CH}_{4}$ emissions ensemble provides $\mathrm{CH}_{4}$ fluxes and the associated uncertainty estimates based on four wetland extent parameterizations, nine terrestrial biosphere models of heterotrophic respiration and three $\mathrm{CH}_{4}: \mathrm{C}$ temperature parameterizations. Global monthly $0.5^{\circ} \times 0.5^{\circ}$ emissions and their associated uncertainty structure span 2009-2010 (full ensemble, henceforth FE); we also evaluate a subset of the model ensemble spanning 2001-2015 (extended ensemble, henceforth $\mathrm{EE}$ ). We validate $\mathrm{FE}$ and $\mathrm{EE}$ 
emissions against a range of regional $\mathrm{CH}_{4}$ emission estimates. Finally, we incorporate FE, EE and existing wetland emission inventories into GEOS-Chem and evaluate the atmospheric $\mathrm{CH}_{4}$ simulations against 104 surface $\mathrm{CH}_{4}$ measurement sites.

\subsection{Wetland $\mathrm{CH}_{4}$ emissions and uncertainty}

We derive wetland $\mathrm{CH}_{4}$ emissions $F\left(\mathrm{mg} \mathrm{CH}_{4} \mathrm{~m}^{-2}\right.$ day $\left.^{-1}\right)$ at time $t$ and location $x$ as

$F(t, x)=s A(t, x) R(t, x) q_{10}^{\frac{T(t, x)}{10}}$,

where $A(t, x)$ is the wetland extent fraction, $R(t, x)$ is the $\mathrm{C}$ heterotrophic respiration per unit area at time $t, q_{10}^{T(t, x) / 10}$ is the temperature dependence of the ratio of $\mathrm{C}$ respired as $\mathrm{CH}_{4}$ (where $q_{10}$ is the relative $\mathrm{CH}_{4}: \mathrm{C}$ respiration for a $10^{\circ} \mathrm{C}$ increase and $T(t, x)$ is the surface skin temperature) and $s$ is a global scaling factor. This empirical parameterization provides first-order constraints on the role of carbon, water and temperature variability in the global spatial and temporal variability of wetland $\mathrm{CH}_{4}$ emissions. Variants of the Eq. (1) parameterization have been used within a range of wetland $\mathrm{CH}_{4}$ emission models (e.g. Hodson et al., 2011; PickettHeaps et al., 2011; Bloom et al., 2012; Melton et al., 2013).

In our approach, wetland $\mathrm{CH}_{4}$ emission statistics within and across $0.5^{\circ} \times 0.5^{\circ}$ grid cells are derived based on an ensemble of wetland $\mathrm{CH}_{4}$ emission simulations. The 324member $\mathrm{FE}$ is based on $3 \mathrm{CH}_{4}: \mathrm{C}$ temperature dependencies, 9 heterotrophic respiration configurations, 4 wetland extent scenarios and 3 global-scale factor configurations $(3 \times 9 \times 4 \times 3=324)$; the 18 -member EE ensemble is a subset of FE based on data availability during 2001-2015 (see Table 1 for details).

The heterotrophic respiration configurations are derived from eight terrestrial biosphere models used in the Multi-scale Synthesis and Terrestrial Model Intercomparison Project (MsTMIP BG1 simulations; see Huntzinger et al. (2013) and Wei et al. (2014) for the model and experiment details) and the global CARbon DAta MOdel fraMework (CARDAMOM) terrestrial carbon analysis (Bloom et al., 2016). V1.0 outputs from the MsTMIP are available for the period 1900-2010 (Huntzinger et al., 2016), and the CARDAMOM analysis was extended to span 2001-2015 based on the Bloom et al. (2016) methodology (see Appendix A for details). Since MsTMIP and CARDAMOM respiration estimates vary intrinsically as a function of temperature, $q_{10}$ only accounts for the temperature dependence of the fraction of $\mathrm{C}$ respired as $\mathrm{CH}_{4}$. We prescribe three $\mathrm{CH}_{4}: \mathrm{C}$ temperature dependencies (Table 1) which are broadly equivalent to a $\pm 50 \%$ range on the $\mathrm{CH}_{4}: \mathrm{CO}_{2}$ temperature dependence reported by Yvon-Durocher et al. (2014).

Here we use two spatial $(i=1,2)$ and two temporal $(j=$ $1,2)$ wetland extent parameterization approaches to represent the uncertainty associated with the role of hydrology in wet- land $\mathrm{CH}_{4}$ emissions. Each temporal and spatial wetland extent parameterization, $A_{i, j}(t, x)$, is derived as

$A_{i, j}(t, x)=w_{i}(x) h_{i, j}(t, x)$,

where $w_{i}(x)$ represents the wetland extent fraction, and $h_{i, j}(t, x)$ represents the temporal variability relative to $w_{i}(x)$. $w_{1}(x)$ is the sum of all GLOBCOVER wetland and freshwater land cover types (all flooded, waterlogged and inland water body land cover types; Bontemps et al., 2011); $w_{2}(x)$ is the Global Lakes and Wetlands Database (GLWD) maximum recorded wetland and freshwater body extent map by Lehner and Döll (2004).

For $h_{*, j}(t, x)$, we use (a) the Surface WAter Microwave Product Series (SWAMPS) multi-satellite surface water product (Schroeder et al., 2015; $j=1$ ) and the (b) monthly ERA-Interim precipitation $(j=2)$. For $i=1 \quad(i=2)$, $h_{i, j}(t, x)$ is normalized such that the mean (maximum) $h_{i, j}(t, x)$ is equal to 1 . In order avoid physically unrealistic outcomes, we derive $A_{1, j}(t, x)$ as $\min \left\{w_{1}(x) h_{1, j}(t, x), 1\right\}$, where the "min \{\} " function represents the minimum between the two bracketed values.

We note that the two hydrological proxies provide contrasting advantages and disadvantages. Satellite-retrieved surface water extent provides an observation-based constraint on the spatial and temporal extent of wetlands and freshwater bodies. While our temporal scaling of static wetland and freshwater extent mitigates the role of spatial biases in satellite-retrieved inundation, vegetation cover remains a major confounding variable in satellite-constrained wetland extent (Schroeder et al., 2015). Moreover, satellites cannot directly observe subsurface soil saturation, even though these soils amount to significant $\mathrm{CH}_{4}$ fluxes to the atmosphere (Turetsky et al., 2014). On the other hand, precipitation does not provide a direct constraint on the wetland and freshwater extent; however, it provides an aggregate constraint on ecosystem hydrological variability and wall-to-wall coverage across the globe. We henceforth refer to $F$ as "wetland $\mathrm{CH}_{4}$ emissions"; however, we recognize that lakes, rivers and reservoirs account for $\sim 20 \%$ of the total wetland and freshwater body extent (Lehner and Döll, 2004). We discuss the implications of including non-wetland freshwater bodies in Sect. 4.

For each of the $324 \mathrm{FE}$ configurations $(c=1-324)$ and 18 EE configurations $(c=1-18)$, we derive $s_{c}$ such that

$s_{c}=\frac{G}{\Sigma_{t} \Sigma_{x} F_{c}(t, x) a(x) \frac{\Delta t}{n}}$,

where $F_{c}(t, x)$ are the $c$ th ensemble member emissions at grid cell $x$ and time $t, a(x)$ is the area of grid cell $x$, $\Delta t$ is the time step (1 month), $n$ is the number of years and $G$ is the global total $\mathrm{CH}_{4}$ emitted from wetlands. We derive $s_{c}$ such that the FE and $\mathrm{EE}$ ensemble members amount to a mean global annual flux of $G=124.5$, 166 or $207.5 \mathrm{~g} \mathrm{CH}_{4} \mathrm{yr}^{-1}$ during 2009-2010. The prescribed 
Table 1. Wetland $\mathrm{CH}_{4}$ model ensemble configurations.

\begin{tabular}{|c|c|c|}
\hline Parameter & Description & Ensemble configurations \\
\hline$s$ & Global scaling factor & $\begin{array}{l}3 \text { configurations: emissions are scaled such that } 2009-2010 \\
\text { emissions amount to } 124.5,166 \text { or } 207.5 \mathrm{Tg} \mathrm{CH}_{4} \mathrm{yr}^{-1}\end{array}$ \\
\hline$A$ & Wetland extent & $\begin{array}{l}2 \text { spatial extent parameterization (scaled using GLOBCOVER } \\
\text { and GLWD) } \\
2 \text { temporal variability parameterizations (SWAMPS inundation } \\
\text { extent* and ERA-Interim precipitation) }\end{array}$ \\
\hline$R$ & Heterotrophic respiration & $\begin{array}{l}8 \text { MsTMIP terrestrial C models* } \\
\text { CARDAMOM terrestrial C cycle analysis }\end{array}$ \\
\hline$q_{10}(c)$ & Temperature-dependent $\mathrm{CH}_{4}$ respiration fraction & $3 \mathrm{CH}_{4}: \mathrm{C}$ temperature parameterizations; $q_{10(c)}=[1,2,3]$ \\
\hline
\end{tabular}

* These datasets are only used in the 2009-2010 "full ensemble" (FE).

range of total wetland $\mathrm{CH}_{4}$ emissions spans the Saunois et al. (2016) mean 2000-2009 top-down wetland $\mathrm{CH}_{4}$ emission estimates (166 $\mathrm{Tg} \mathrm{CH}_{4} \mathrm{yr}^{-1} ; 125-204 \mathrm{Tg} \mathrm{CH}_{4} \mathrm{yr}^{-1}$ ).

We attribute the uncertainty in the timing and magnitude of $F(t, x)$ (namely, the maximum $\mathrm{CH}_{4}$ emission month, mean $\mathrm{CH}_{4}$ emissions and $\mathrm{CH}_{4}$ emission variability) to carbon decomposition, wetland extent and $\mathrm{CH}_{4}: \mathrm{C}$ temperature dependence uncertainty. The derivation of the "dominant uncertainty" within each zonal band (i.e. the dominance of carbon, water or temperature as the dominant source of uncertainty) is fully described in Appendix C.

\subsection{GEOS-Chem atmospheric $\mathrm{CH}_{4}$ simulations}

We evaluate the $\mathrm{FE}$ and $\mathrm{EE}$ wetland $\mathrm{CH}_{4}$ emission means against the World Data Centre for Greenhouse Gases (WDCGG) $\mathrm{CH}_{4}$ measurement sites by incorporating these into the $4^{\circ} \times 5^{\circ}$ resolution GEOS-Chem atmospheric chemical and transport model (version 10.01; acmg.seas.harvard.edu/ geos). We benchmark the FE and EE runs against GEOSChem simulations with the GEOS-Chem wetland $\mathrm{CH}_{4}$ emissions inventory (Pickett-Heaps et al., 2011; 2009-2010 derivation described in Turner et al., 2015; henceforth GC) and the Bloom et al. (2012) satellite-constrained wetland emissions (henceforth BL), as these emission estimates have been used in a range of atmospheric chemical transport model simulations (Fraser et al., 2013; Turner et al., 2015; and Wilson et al., 2016, amongst others). We perform each GEOS-Chem forward run for the period 2009-2010 with a 4-year (2005-2009) spin-up period. The non-wetland $\mathrm{CH}_{4}$ sources in GEOS-Chem consist of biofuel, fossil fuel, livestock, waste, rice (EDGAR v4.2; European Commission, 2011), fires (Global Fire Emissions Database version 4; van der Werf et al., 2010), soil C sinks and termites (Fung et al., 1991). The non-wetland $\mathrm{CH}_{4}$ fluxes are the same in each run, with the exception of the rice source in run BL (as global wetland and rice emissions are treated as one source by Bloom et al., 2012). While model $\mathrm{CH}_{4}$ surface concentrations are strongly influenced by wetland $\mathrm{CH}_{4}$ magnitude, timing and distribution (Bloom et al., 2012; Meng et al., 2015), comparisons between GEOS-Chem outputs and surface $\mathrm{CH}_{4}$ measurements may also be affected by errors in non-wetland $\mathrm{CH}_{4}$ emissions and in transport. However, Wecht et al. (2012) and Turner et al. (2015) show that the GEOS-Chem emissions and transport provide an unbiased representation of the observed latitudinal background. The global inversion of Turner et al. (2015) using GEOS-Chem emissions as prior further shows no large errors in non-wetland emissions that would confound the analysis presented here.

For each of the four runs (FE, EE, GC and BL), we use the Wecht et al. (2014b) 1 January 2005 initial conditions for atmospheric $\mathrm{CH}_{4}$ concentrations in GEOS-Chem. For each simulation, we performed a 4-year spin-up period (20052009) using 2009 emissions to reduce the potential inconsistency between the initial conditions and the global distribution of wetland $\mathrm{CH}_{4}$ emissions; this spin-up ensures that the relative variations in 1 January $2009 \mathrm{CH}_{4}$ concentrations for each run are broadly consistent with each emission scenario. We save GEOS-Chem atmospheric $\mathrm{CH}_{4}$ concentrations every $3 \mathrm{~h}$. We compare the mean monthly GEOS-Chem output against all WDCGG sites (104 sites with monthly 2009-2010 data in total). For each site, the nearest $4^{\circ} \times 5^{\circ}$ GEOS-Chem grid cell is used for comparison. We note that the GEOSChem analysis outlined here is not a direct validation of FE and EE; rather, it provides supporting evidence for the plausibility of FE and EE emissions relative to existing wetland $\mathrm{CH}_{4}$ emission datasets.

\section{Results, comparison and validation}

Mean full ensemble (FE) global wetland emissions are largely accounted for by three high-latitude regions, three tropical regions and subtropical southeast Asia (Fig. 1). North American, Scandinavian and Siberian median (5th95th percentiles) $\mathrm{CH}_{4}$ fluxes amount to $10 \%(3-30 \%), 2 \%$ 

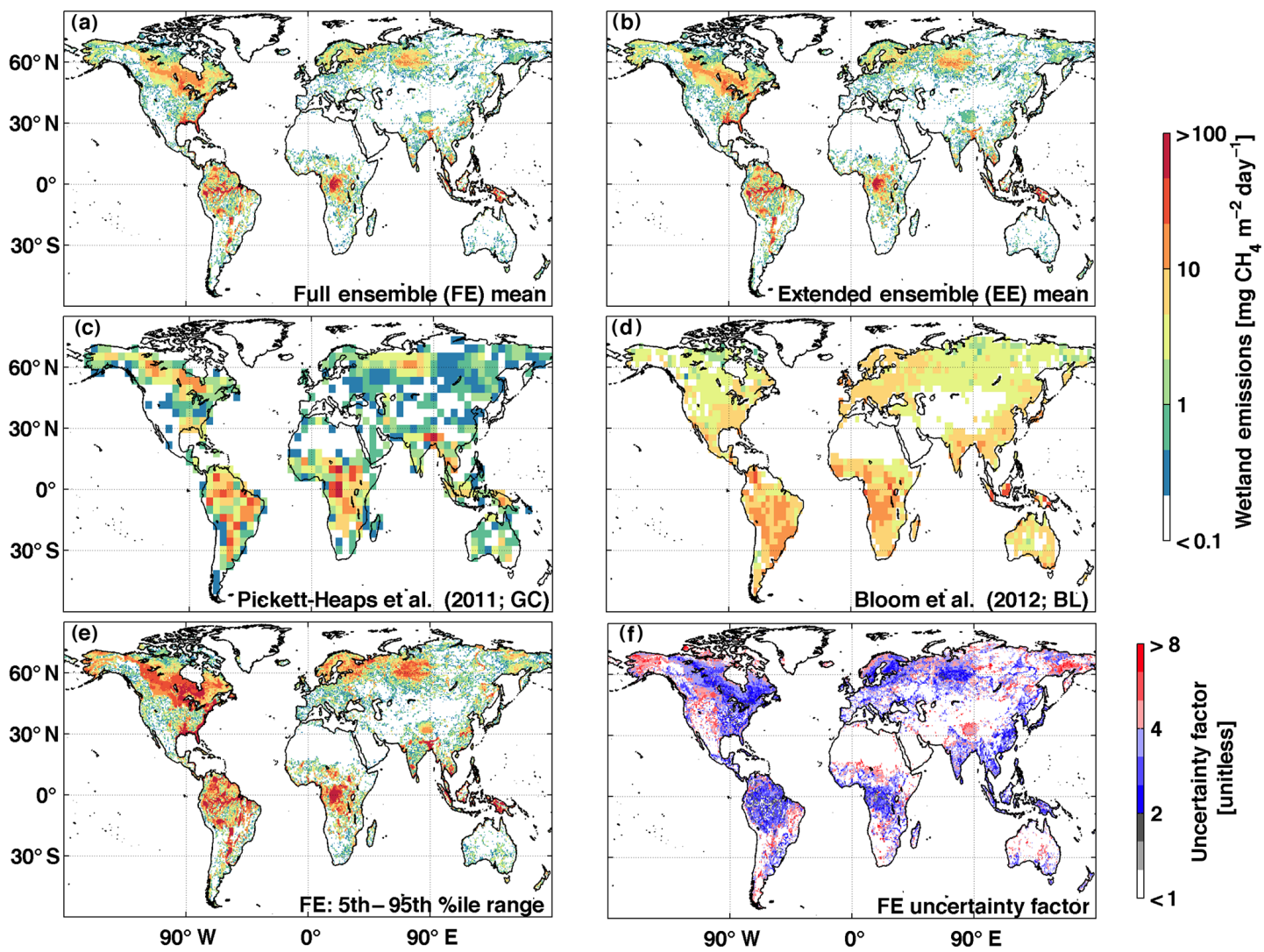

Figure 1. Top row (a, b): 2009-2010 full model ensemble (FE; left) and extended model ensemble (EE; right) mean wetland $\mathrm{CH}_{4}$ emissions. Middle row (c, d): 2009-2010 emissions from the GEOS-Chem wetland $\mathrm{CH}_{4}$ emissions inventory (GC; left) model and the satelliteconstrained estimates by Bloom et al. (2012) (BL; right). Bottom row (e, f): mean 2009-2010 FE 5th-95th percentile range (left) and uncertainty factor (5th-95th percentile range normalized by mean 2009-2010 emissions; right).

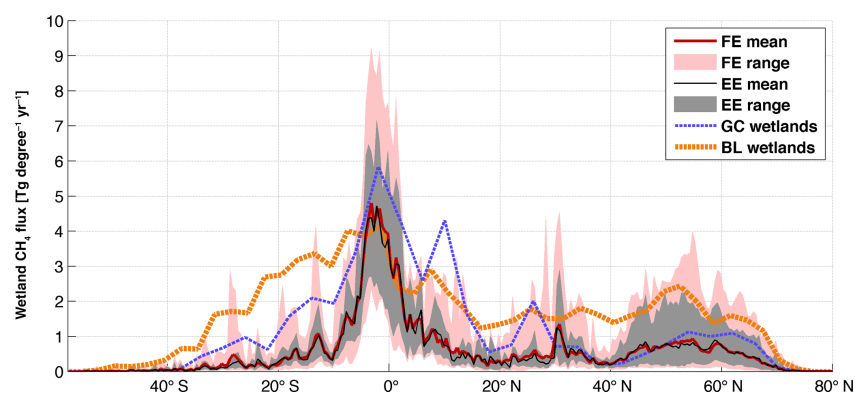

Figure 2. Mean wetland $\mathrm{CH}_{4}$ emission zonal profiles: full ensemble mean (FE: red line) and corresponding range (pink area); extended ensemble mean (EE; black line) and corresponding range (grey area); GEOS-Chem emissions inventory (GC; dashed blue line); Bloom et al. (2012) emissions (BL; dashed orange line).

(1-6\%) and $2 \%(1-6 \%)$ of global emissions, respectively. Amazon wetland emissions (29\%; 20-37\%) account for the largest tropical emission source, followed by the Indonesian archipelago (13\%; 7-23\%) and central Africa (12\%; 7-23\%). Subtropical southeast Asian emissions account for $5 \%(1-10 \%)$. High-latitude $\left(>50^{\circ} \mathrm{N}\right)$ and tropical emis- sions amount to $12 \%(5-31 \%)$ and $66 \%(43-83 \%)$ of global wetland $\mathrm{CH}_{4}$ emissions, respectively. Gridded $\mathrm{FE}$ uncertainties (shown as the 5th-95th percentile ranges; Fig. 1e) are largely comparable in magnitude to FE emissions (Fig. 1a). Relative FE uncertainties (shown as the ratio of the $90 \%$ confidence range to mean emissions in Fig. 1f) are the lowest in high-emission areas, notably the wetland regions in the Amazon and Congo basins, North America and western Eurasia.

Mean FE and extended ensemble (EE) $\mathrm{CH}_{4}$ emission patterns exhibit close agreement across all tropical continents and the high northern-latitude wetland regions (Fig. 1a and b). The comparison between zonal mean emissions (Fig. 2) reveals differences of less than $1 \mathrm{Tg} / \mathrm{yr} /{ }^{\circ}$ lat between FE and EE. On a continental scale, FE and EE emission patterns are in broad agreement with the Pickett-Heaps et al. (2011) wetland $\mathrm{CH}_{4}$ emissions (GC; Fig. 1c) and the Bloom et al. (2012) emissions (BL; Fig. 1d). High-latitude FE and EE emissions peak roughly between 45 and $60^{\circ} \mathrm{N}$ (Fig. 2), which is in agreement with GC and BL emission peaks $(\sim 60$ and $\sim 50^{\circ} \mathrm{N}$, respectively) and tropical emissions for all four emission dataset peaks within $0-5^{\circ} \mathrm{S}$. The FE zonal mean is comparable to the $\mathrm{BL}$ in the near-equatorial tropics and 

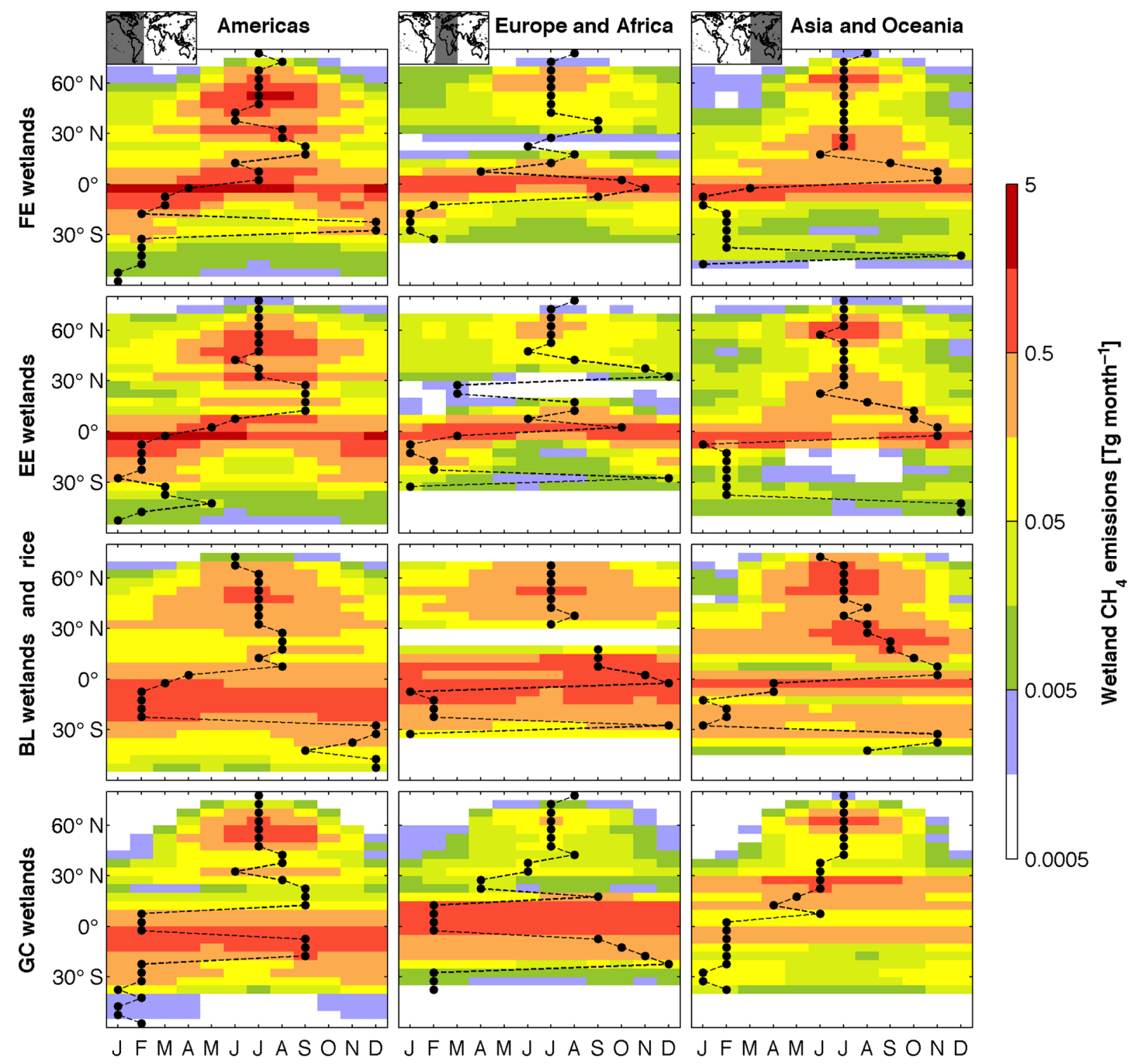

Figure 3. Seasonally averaged 2009-2010 wetland $\mathrm{CH}_{4}$ emissions for this study (full ensemble: FE; extended ensemble: EE), Bloom et al. (2012) wetland emissions (BL) and GEOS-Chem wetland emissions inventory (GC) across North and South America (left column; 180$35^{\circ} \mathrm{W}$ ), Europe and Africa (centre column; $35^{\circ} \mathrm{W}-55^{\circ} \mathrm{E}$ ) and Asia and Oceania (right column; 55-180 $\mathrm{E}$ ). The emissions for each region are reported as total monthly fluxes across $5^{\circ}$ latitude bins. The black dotted line denotes the maximum emission month within each $5^{\circ}$ latitude bin.

significantly lower (with respect to the FE model ensemble $90 \%$ confidence range) everywhere else; the FE zonal mean is comparable to GC in high-latitude and temperate regions, but significantly lower than GC in the tropics and the Southern Hemisphere.

All $\mathrm{CH}_{4}$ emission models show similar patterns in the temporal distribution of $\mathrm{CH}_{4}$ emissions in high-latitude and temperate regions (with $\mathrm{CH}_{4}$ emissions peaking between July and September; Fig. 3). We note that the larger $\mathrm{CH}_{4}$ fluxes in the $\mathrm{BL}$ emissions over Asia and Oceania are due to rice paddy $\mathrm{CH}_{4}$ emissions. All emission models exhibit highlatitude $\left(>50^{\circ} \mathrm{N}\right)$ maximum $\mathrm{CH}_{4}$ emissions between June and August. In tropical South America $\left(0-20^{\circ} \mathrm{S}\right), \mathrm{FE}$ and EE emissions peak between February and April, which is comparable to BL (February-March) and overall earlier than
GC (5-20 ${ }^{\circ} \mathrm{S}$ emission peak in September). There is considerable disagreement between northern tropical African emission variability amongst all models, with $0-15^{\circ} \mathrm{N}$ emissions peaking in February (GC), April-October (FE, EE) and September-November (BL). Subtropical Asian FE and EE emissions $\left(20-30^{\circ} \mathrm{N}\right)$ peak in June-July, earlier than BL emissions (August-September) and comparable to GC emissions (June).

We compare the mean FE and EE (2009-2010) wetland emissions against a range of independent wetland $\mathrm{CH}_{4}$ regional emission estimates (Fig. 4). Emissions from the Siberian wetlands (Glagolev et al., 2011), the Hudson Bay lowlands (Pickett-Heaps et al., 2011) and the Amazon River basin (Melack et al., 2004) are within the 25th75th percentile estimates of $\mathrm{FE}$ and $\mathrm{EE}$ wetland $\mathrm{CH}_{4}$ emis- 


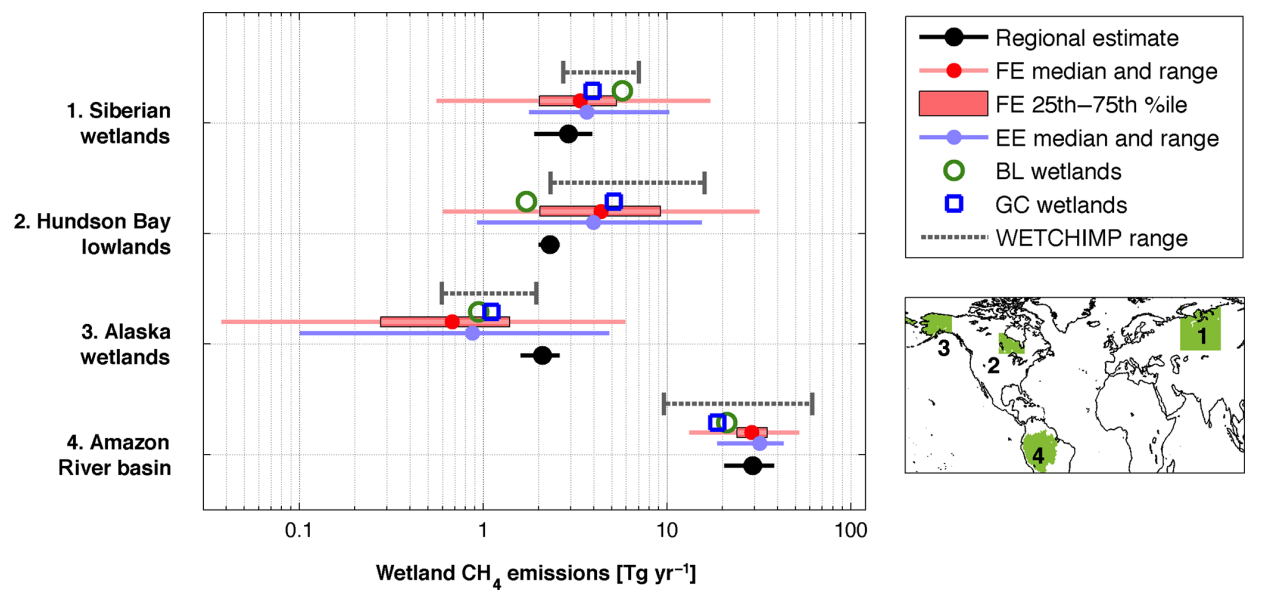

Figure 4. A comparison between the mean annual regional wetland $\mathrm{CH}_{4}$ emission estimates of (1) Glagolev et al. (2011), (2) Pickett-Heaps et al. (2011), (3) Chang et al. (2014) and (4) Melack et al. (2004) and the global wetland emission datasets by Bloom et al. (2012) (BL), the GEOS-Chem wetland $\mathrm{CH}_{4}$ emissions inventory (GC), this study (full ensemble: FE; extended ensemble: EE) and the range of WETCHIMP models (Melton et al., 2013). Wetland emissions (horizontal axis) correspond to the mean annual totals within the regions shown in the inset map.

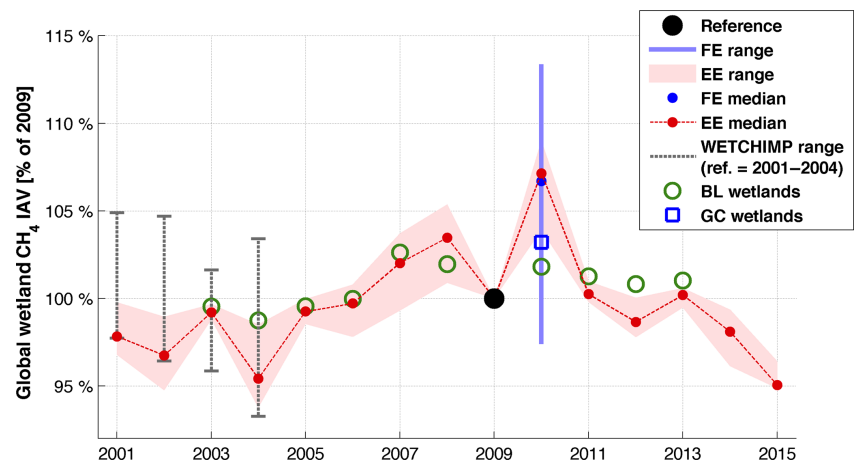

Figure 5. The global wetland $\mathrm{CH}_{4}$ emission inter-annual variability range of the FE (2009-2010) and EE (2001-2015) emission models, normalized relative to 2009 emissions; the WETCHIMP (Melton et al., 2013) model ensemble inter-annual variability is normalized relative to 2001-2004 mean emissions.

sions. Alaskan wetland emissions (Chang et al., 2014; MaySeptember) are higher $\left(2.1 \mathrm{Tg} \mathrm{CH}_{4} \mathrm{yr}^{-1}\right)$ but within the 5th95th percentile range of $\mathrm{FE}$ and $\mathrm{EE}$ wetland $\mathrm{CH}_{4}$ emission estimates. With the exception of the Amazon River basin estimates, the FE and EE emission uncertainty estimates are larger than the Melton et al. (2013) wetland $\mathrm{CH}_{4}$ emission model (WETCHIMP 1993-2004) range. BL (20092010) and GC (2009-2010) estimates are also within all regional 5th-95th percentile ranges. We note the temporal mismatch between the modelled and regional wetland $\mathrm{CH}_{4}$ emission estimates in Fig. 4; however, based on a range of process model approaches (e.g. Bloom et al., 2010; Melton et al., 2013), we expect the inter-annual variation in wetland $\mathrm{CH}_{4}$ emissions to be substantially smaller than the FE and $\mathrm{EE}$ estimate uncertainty. For example, the maximum-

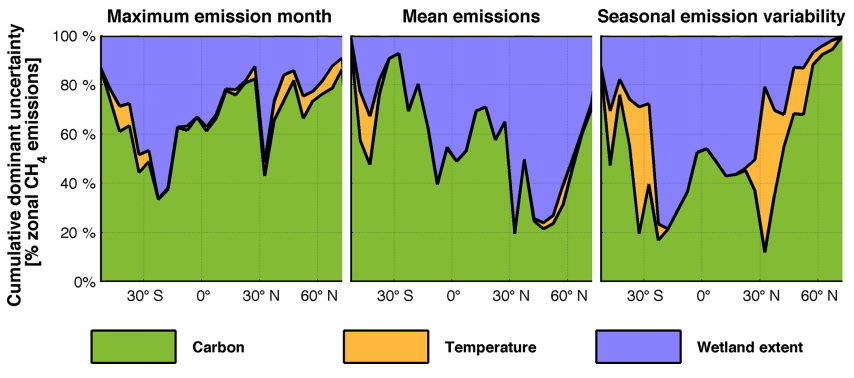

Figure 6. The dominant uncertainty attribution of the maximum $\mathrm{CH}_{4}$ emission month (left), magnitude (centre) and seasonal variability (right) to carbon decomposition, temperature $\mathrm{CH}_{4}$ : $\mathrm{C}$ dependence $\left(q_{10}\right)$ and wetland extent parameterization within $5^{\circ}$ latitude bins. The derivation of dominant uncertainties is described in Appendix C.

to-minimum ratios of WETCHIMP 1993-2004 annual emissions are $\leq 5.1$ across the three extratropical regions and $\leq$ 1.4 in the Amazon River basin; in contrast, FE and EE uncertainty intervals span factors of 5.8-156.3 in the extratropics and 2.3-3.9 in the Amazon River basin.

FE and EE ensemble models exhibit a median of 6.7 and a $7.2 \%$ increase in global emissions between 2009 and 2010 (Fig. 5). BL and GC changes from 2009 to $2010(+1.8$ and $+3.2 \%)$ are within the FE uncertainty range $(-2.6$ to $+13.4 \%$ ). Uncertainties in the WETCHIMP inter-annual variations (IAV; relative to the 2001-2004 model means) are larger than EE IAV uncertainty throughout 2001-2015 (relative to 2009) and smaller than the FE change uncertainty for 2009 to 2010. For the 2003-2013 period, BL IAV is generally lower or within the range of EE IAV. In comparison to regional top-down constraints, we find that the regional EE IAV 


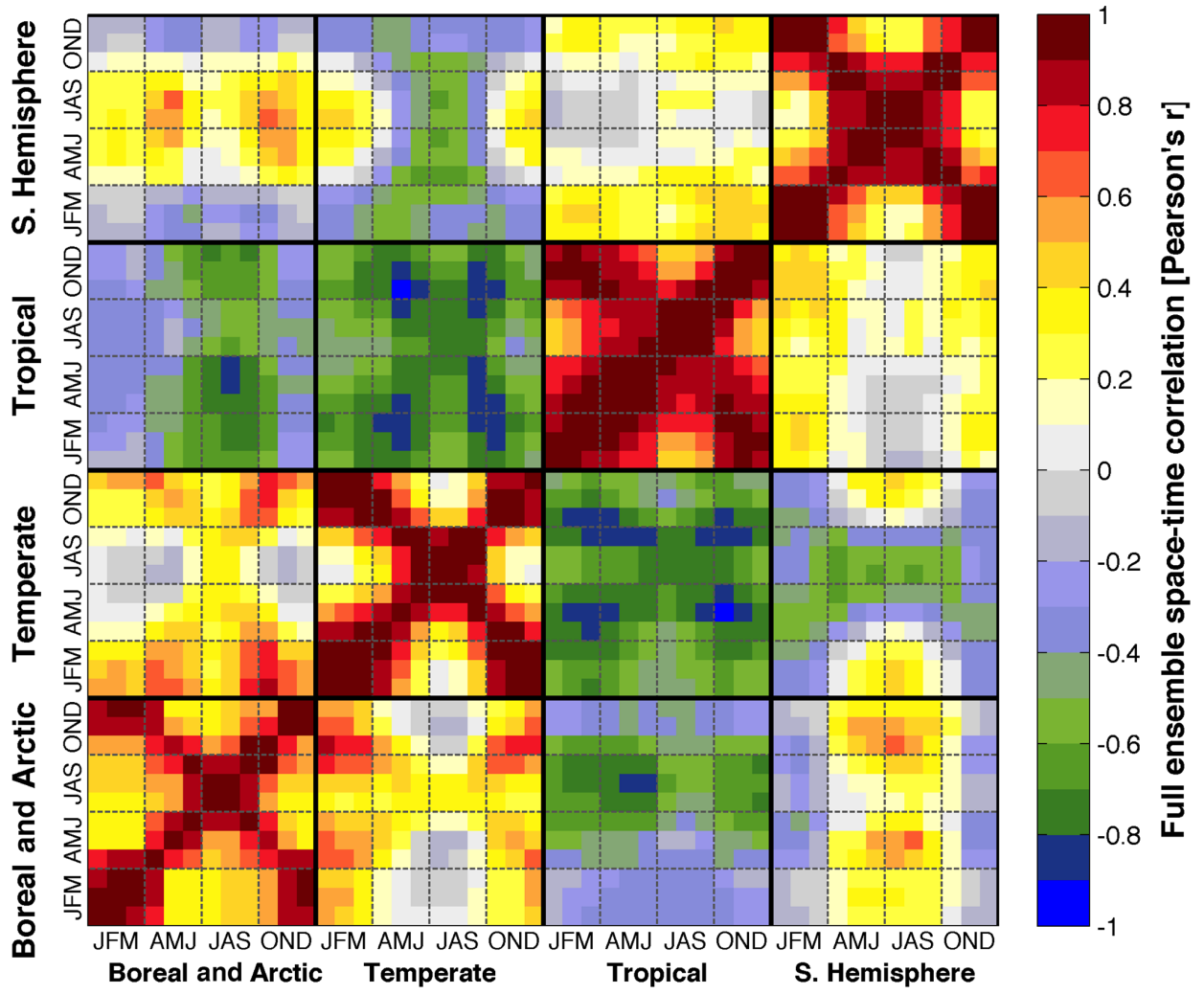

Figure 7. The full ensemble (FE) spatial and temporal error covariance, summarized as a monthly error correlation across boreal and Arctic $\left(>55^{\circ} \mathrm{N}\right)$ temperate $\left(23-55^{\circ} \mathrm{N}\right)$, tropical $\left(23^{\circ} \mathrm{S}-23^{\circ} \mathrm{N}\right)$ and Southern Hemisphere $\left(<23^{\circ} \mathrm{S}\right)$ latitudes. A correlation between two locationand-time indices indicates the degree to which models consistently over- or under-predict wetland $\mathrm{CH}_{4}$ emissions relative to the ensemble mean. The non-zero off-diagonal correlation patterns emerge as a function of varying biogeochemical commonalities across ensemble members, such as wetland $\mathrm{CH}_{4}$ dependencies on temperature, carbon availability and wetland extent. Negative correlations between tropical and Northern Hemisphere extratropical (i.e. temperate, boreal and Arctic) wetlands emerge as a function of a global constraint on wetland $\mathrm{CH}_{4}$ emissions (166 $\mathrm{Tg} \mathrm{CH}_{4} \mathrm{yr}^{-1} \pm 25 \%$ ).

is comparable to the Miller et al. (2016) 2012-2014 annual Alaskan wetland emission variability (coefficient of variation observed $=4.9 \%, \mathrm{EE}=4.2-6.9 \%)$, and within the Wilson et al. (2016) constraints on the change in annual Amazon wetland emissions for 2010 to 2011 (coefficient of variation: observed $<20 \%$; $\mathrm{EE}=0.5-2.9 \%$ ).

On a zonal basis, the "dominant uncertainty", i.e. the dominant source of uncertainty within each band, in mean $\mathrm{CH}_{4}$ emissions and the timing of maximum $\mathrm{CH}_{4}$ emissions is almost completely dominated by carbon decomposition and wetland extent uncertainties (Fig. 6). Seasonal variability in $\mathrm{CH}_{4}$ emissions is also largely dominated by carbon and extent uncertainties, although the temperature $\mathrm{CH}_{4}: \mathrm{C}$ dependence is the dominant source of uncertainty in temperate latitudes. At latitudes $>20^{\circ} \mathrm{N}$, wetland extent is the dominant source of uncertainty in mean $\mathrm{CH}_{4}$ emissions, while the temperature $\mathrm{CH}_{4}$ : $\mathrm{C}$ dependence accounts for $<5 \%$ of the dominant uncertainty attribution. Across tropical latitudes $\left(23^{\circ} \mathrm{S}-\right.$ $\left.23^{\circ} \mathrm{N}\right)$ and northern high latitudes $\left(>45^{\circ} \mathrm{N}\right)$, carbon decomposition is the dominant source of uncertainty in the timing of wetland $\mathrm{CH}_{4}$ emissions.
We summarize the FE global error covariance structure as an error correlation matrix between mean monthly 20092010 emissions across boreal and Arctic $\left(>55^{\circ} \mathrm{N}\right)$ temperate $\left(23-55^{\circ} \mathrm{N}\right)$, tropical $\left(23^{\circ} \mathrm{S}-23^{\circ} \mathrm{N}\right)$ and Southern Hemisphere $\left(<23^{\circ} \mathrm{S}\right)$ latitudes (Fig. 7$)$; the error correlation matrix quantitatively summarizes similarities in the spatial and temporal patterns between ensemble members relative to the ensemble mean (see Appendix B for a description and interpretation). The FE error correlation matrix highlights the positively correlated ensemble member $\mathrm{CH}_{4}$ emissions within each region, with larger correlations (generally Pearson's $r>0.8$ ) between emissions separated by 1-2 months. Tropical emissions exhibit the largest overall temporal correlations $(r>0.5)$. Tropical emissions exhibit negative correlations against temperate emissions $(r<-0.3)$ and boreal and Arctic $\mathrm{CH}_{4}$ emissions $(r<-0.1)$.

Mean 2009-2010 observed and GEOS-Chem forward model run $\mathrm{CH}_{4}$ concentrations (with $\mathrm{FE}, \mathrm{EE}, \mathrm{BL}$ and $\mathrm{GC}$ wetland emissions) are broadly consistent on a latitudinal basis. The observed and modelled zonal atmospheric $\mathrm{CH}_{4}$ concentration anomaly (relative to mean global 2009-2010 


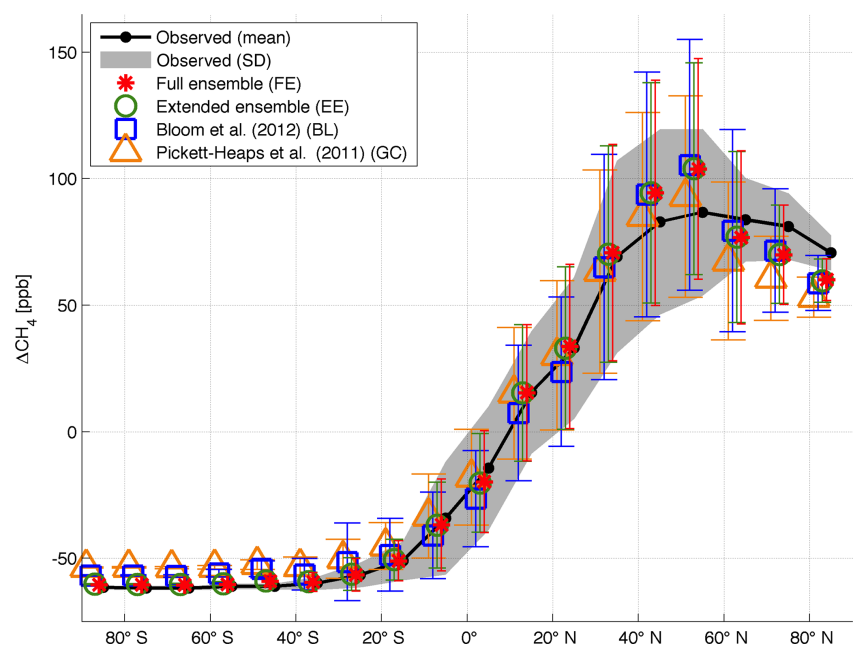

Figure 8. Mean 2009-2010 $\mathrm{CH}_{4}$ measurements and model $\mathrm{CH}_{4}$ zonal anomalies $\left(\Delta \mathrm{CH}_{4}\right)$ relative to the mean 2009-2010 global $\mathrm{CH}_{4}$ concentration. The black dots denote the mean WDCGG network observed $\mathrm{CH}_{4}$ concentrations within $5^{\circ}$ latitude bins; the grey envelope denotes the mean 2009-2010 standard deviation across all sites within $5^{\circ}$ latitude bins. The coloured symbols and error bars denote the GEOS-Chem equivalent model concentration statistics based on the FE and EE ensembles (this study), Bloom et al. (2012) (BL) and the GEOS-Chem emissions inventory (GC) wetland $\mathrm{CH}_{4}$ emission datasets.

$\mathrm{CH}_{4}$ concentrations) is shown in Fig. 8 (the zonal profile root mean square errors (RMSEs) are 6.5, 6.6, 8.4 and $9.2 \mathrm{ppb}$ for FE, EE, BL and GC relative to the observed $\mathrm{CH}_{4}$ anomaly zonal profile). Within the primary wetland $\mathrm{CH}_{4}$ emission latitudes $\left(10^{\circ} \mathrm{S}-80^{\circ} \mathrm{N}\right.$; Fig. 2), all mean $\mathrm{CH}_{4}$ model estimates are within the mean standard deviation of observed $\mathrm{CH}_{4}$, except for GC at $>60^{\circ} \mathrm{N}$ and all models at $80^{\circ} \mathrm{N}$.

The median site-level correlation (Pearson's $r$ ) between the observed and modelled de-trended $\mathrm{CH}_{4}$ concentrations (Fig. 9) is the highest for BL (0.75), followed by EE (0.74), FE (0.73) and GC (0.72). The median RMSEs between the observed and modelled de-trended $\mathrm{CH}_{4}$ concentrations for FE (11.78 ppb) and EE (11.89 ppb) are lower than BL (12.42 ppb) and GC (13.27 ppb). FE and EE improvements (relative to GC and BL Pearson's $r$ and RMSE) are primarily in Northern Hemisphere high latitudes ( $>50^{\circ} \mathrm{N}$; Fig. 9). In the Southern Hemisphere extratropical latitudes $\left(<23^{\circ} S\right)$, FE and EE exhibit a comparable performance relative to GC, while BL outperforms both FE and EE.

\section{Discussion}

\subsection{Model limitations}

Densely vegetated wetland areas are likely to amount to a large component of the global wetland $\mathrm{CH}_{4}$ sources; a high carbon density (and high temperatures in the case of tropical wetlands) results in high $\mathrm{CH}_{4}$ emissions under inundated conditions. However, satellite-derived observations of surface water area (Schroeder et al., 2015) are ill-equipped to observe densely vegetated wetland areas, as the passive microwave sensors become increasingly sensitive to vegetation moisture within high-biomass ecosystems (Sippel et al., 1994). For example, FE estimates of Amazon River basin wetland $\mathrm{CH}_{4}$ emissions amount to 16-29\% (5th-95th percentiles) of the global wetland emissions source; the high biomass density in this region (Saatchi et al., 2011) may be a significant source of inundation area bias. Therefore, while we incorporate prior information on the mean and maximum wetland extent to scale the satellite-derived inundation fraction, we anticipate that errors in seasonal and inter-annual inundation variability are likely to be larger within densely vegetated wetland areas. We are optimistic that current and upcoming missions such as SMAP and BIOMASS (Entekhabi et al., 2010; Le Toan et al., 2011) combined with data integration approaches (Schroeder et al., 2015; Fluet-Chouinard et al., 2015) can potentially provide the additional constraints required to extend current inundation datasets and to improve current surface inundation detection capabilities.

The MsTMIP model ensemble provides a first-order estimate of the magnitude and variability of $\mathrm{C}$ decomposition within each $0.5^{\circ} \times 0.5^{\circ}$ grid cell. Here we highlight four potentially major sources of error: (a) differences in aerobic: anaerobic turnover rates of major (labile and recalcitrant) C pools, (b) systematic differences in wetland and non-inundated area carbon uptake within each $0.5^{\circ} \times 0.5^{\circ}$ grid cell, (c) systematic differences in dead organic matter $\mathrm{C}$ stocks and accumulation between wetland and noninundated areas and (d) lateral flows of $\mathrm{C}$ into (or out of) wetland areas. Top-down estimates of seasonal and inter-annual terrestrial $\mathrm{CO}_{2}$ fluxes (e.g. Liu et al., 2014) could be used to independently assess the validity of heterotrophic respiration from the MsTMIP models and CARDAMOM. In turn, topdown $\mathrm{CH}_{4}$ and $\mathrm{CO}_{2}$ flux retrievals and a range of in situ and regional-scale $\mathrm{CH}_{4}$ flux estimates (Schriel-Uijl et al., 2011; Chang et al., 2014; and Budishchev et al., 2014, amongst others) can be combined to assess whether our empirical parameterization is able to capture regional, seasonal and interannual wetland $\mathrm{CH}_{4}$ emission variability and their link to the broader terrestrial carbon cycle. Finally, in succession to the eddy covariance tower-site analyses of $\mathrm{CO}_{2}$ respiration dependence on temperature (Mahecha et al., 2010), we anticipate that $\mathrm{CH}_{4}$ eddy covariance measurements will provide critical site-level constraints on the temperature dependence of wetland $\mathrm{CH}_{4}$ emissions. 

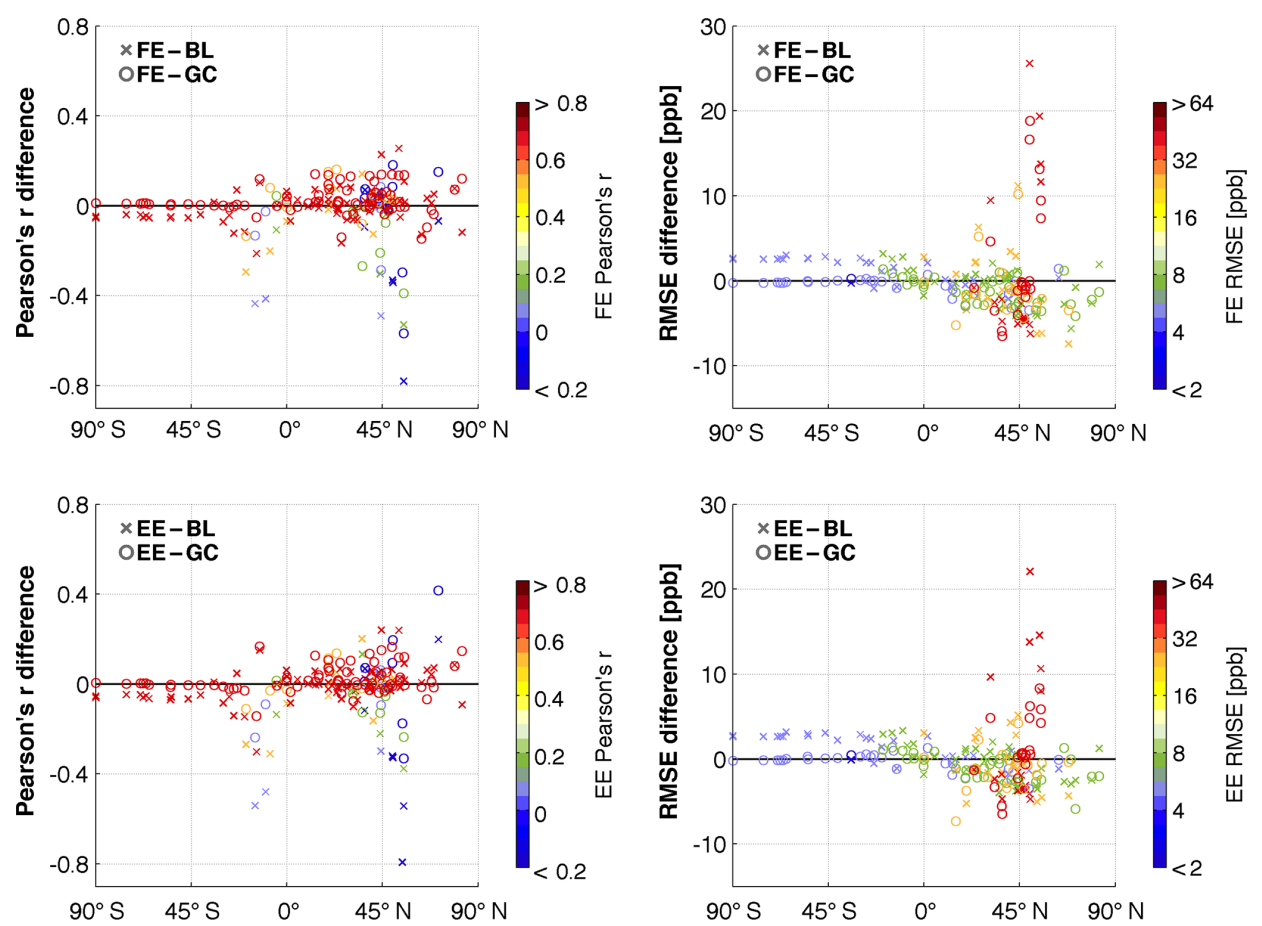

Figure 9. The symbol colours denote the monthly de-trended $\mathrm{CH}_{4}$ Pearson's $r$ correlation (left column) for the model observations and RMSE (right column) for the FE (top row) and EE (bottom row) wetland $\mathrm{CH}_{4}$ emissions (monthly $\mathrm{CH}_{4}$ observations are from the WDCGG measurement site network). The $y$ axis denotes the difference between $\mathrm{FE}$ and $\mathrm{EE}$ and the model runs with $\mathrm{Bloom}$ et al. (2012) wetland $\mathrm{CH}_{4}$ emissions (BL) and the GEOS-Chem wetland $\mathrm{CH}_{4}$ emissions inventory (GC).

Rice paddies likely amount to $<20 \%$ of wetland $\mathrm{CH}_{4}$ emissions, and the majority of rice paddy areas are implicitly excluded from our analysis. GLOBCOVER distinguishes between natural and irrigated water bodies, and GLWD explicitly excludes rice paddy extents in China (which alone account for a large portion of global rice paddy $\mathrm{CH}_{4}$ emissions). However, satellite-based inundation fraction retrievals are unable to distinguish the temporal variability in colocated agriculture and natural wetland inundation extent. Moreover, a $0.5^{\circ} \times 0.5^{\circ}$ carbon cycle model resolution may be insufficient to resolve spatial differences in wetland and agricultural $\mathrm{C}$ cycling. The inadvertent inclusion of colocated rice $\mathrm{CH}_{4}$ emissions is therefore a potential source of bias in our approach. We note that the distinction between wetland and rice $\mathrm{CH}_{4}$ emissions has yet to be consistently addressed in global wetland $\mathrm{CH}_{4}$ emission quantification efforts (see Bloom et al., 2010; Hodson et al., 2011; Melton et al., 2013, and the references therein).

$\mathrm{CH}_{4}$ production in non-wetland freshwater bodies, such as very small ponds (Holgerson and Raymond, 2016), lakes (Wik et al., 2016) and rivers (Bastviken et al., 2011), is potentially a significant, albeit highly uncertain, term in the global $\mathrm{CH}_{4}$ budget (Kirschke et al., 2013; Bridgham et al., 2013). Our approach implicitly accounts for non-wetland freshwater body emissions, since their extent is incorporated in gridcell scaling factors (see Eq. 2). We recognize the challenge in explicitly distinguishing between wetlands and non-wetland freshwater body $\mathrm{CH}_{4}$ emissions, as well as the associated physical and biogeochemical process controls. The quantitative distinction of $\mathrm{CH}_{4}$ emissions from wetland and nonwetland freshwater extent remains challenging with the current spatial resolution $(\sim 25 \mathrm{~km})$ of surface inundation retrievals (Prigent et al., 2007; Schroeder et al., 2015). Equally, the current global carbon cycle model resolutions $\left(\geq 0.5^{\circ}\right)$ are insufficient to resolve spatial variations in heterotrophic processes across $\leq 1 \mathrm{~km}$ of wetland and freshwater land cover definitions (Lehner and Döll, 2004). Contingent on future resolution enhancements in surface inundation and carbon cycle models, we recommend further investigation of the adequate distinction and estimation of non-wetland freshwater $\mathrm{CH}_{4}$ emissions for atmospheric $\mathrm{CH}_{4}$ chemical transport modelling applications.

By constraining global emission estimates to the Saunois et al. (2016) model range, our approach does not challenge the global annual $\mathrm{CH}_{4}$ source and uncertainty; rather, it places constraints on spatial and temporal wetland $\mathrm{CH}_{4}$ source variability. Since the global uncertainty $\left(166 \mathrm{Tg} \mathrm{CH}_{4} \mathrm{yr}^{-1}\right.$; range $\left.= \pm 25 \%\right)$ is substantially smaller than regional uncertainties (spanning a factor of 2-156; see Fig. 4), new or improved constraints on the global wetland $\mathrm{CH}_{4}$ source are unlikely to significantly influence our regional $\mathrm{CH}_{4}$ flux confidence range estimates. We therefore 
anticipate that wetland $\mathrm{CH}_{4}$ in situ measurements and associated up-scaling efforts (e.g. Olefeldt et al., 2013; Turetsky et al., 2014; and Sjörgesten et al., 2014, amongst others) will undoubtedly become critical for reducing emission and process uncertainty in future wetland emission model ensembles.

\subsection{Applications}

Based on comparisons against measured $\mathrm{CH}_{4}$ concentrations and a range of regional and global $\mathrm{CH}_{4}$ emission estimates (Figs. 2-4, 7-8), we have shown that the FE and EE wetland $\mathrm{CH}_{4}$ emission ensembles robustly represent the global magnitude and uncertainty of wetland $\mathrm{CH}_{4}$ emissions. The combined ensemble configurations of inundation extent, carbon decomposition and temperature dependence have provided a characterization of the dominant source of uncertainty in global wetland $\mathrm{CH}_{4}$ estimates (Fig. 6). The approach outlined here provides a framework for producing prior emission estimates and the associated uncertainty. The error covariance structure, along with the $\mathrm{CH}_{4}$ observation system capabilities (Wecht et al., 2014b), can be used to devise an optimal strategy for spatially and/or temporally aggregating $\mathrm{CH}_{4}$ fluxes in an atmospheric inversion framework. The retrieved $\mathrm{CH}_{4}$ flux from assimilating atmospheric $\mathrm{CH}_{4}$ observations in an inverse modelling framework (e.g. Fraser et al., 2013) could in turn provide a quantitative constraint on the wetland ensemble; the FE and EE model members can be treated as an ensemble of probable biogeochemical process hypotheses that can be weighted against atmospheric constraints. In contrast to conventional wetland $\mathrm{CH}_{4}$ emission estimates (Riley et al., 2011; Pickett-Heaps et al., 2011) and model inter-comparisons (Melton et al., 2013), top-down $\mathrm{CH}_{4}$ flux estimates can constrain the joint probability distribution of FE carbon models, wetland extent parameterizations and temperature dependencies. We note that due to the smaller ensemble size and the use of only one carbon model (see Table 1), the 2001-2015 EE emission variability should be interpreted with caution and, where possible, evaluated against the FE ensemble during the 2009-2010 period.

We anticipate extensions of the FE beyond the 2009-2010 time period, contingent on the extensions of the MsTMIP and SWAMPS datasets beyond 2010 and 2012, respectively. In light of continued satellite $\mathrm{CH}_{4}$ retrievals from GOSAT (Parker et al., 2011; Butz et al., 2011) and upcoming satellite $\mathrm{CH}_{4}$ measurements from the TROPOMI on-board ESA Sentinel-5 precursor (Veefkind et al., 2012), we anticipate that the FE and EE datasets will provide key process-based prior knowledge in future atmospheric $\mathrm{CH}_{4}$ inversions.
Data availability. The full ensemble (FE) and extended ensemble (EE) datasets (Bloom et al., 2017) are available from the Oak Ridge National Laboratory Distributed Active Archive Center (ORNL DAAC; http://dx.doi.org/10.3334/ORNLDAAC/1502). MsTMIP monthly $0.5^{\circ} \times 0.5^{\circ}$ datasets (Huntzinger et al., 2016) were obtained from http://nacp.ornl.gov/MsTMIP.shtml. ERAInterim datasets were obtained from http://apps.ecmwf.int/datasets/ data/interim-full-mnth. CARDAMOM 2001-2010 heterotrophic respiration outputs are available at http://datashare.is.ed.ac.uk/ handle/10283/875; the complete 2001-2015 heterotrophic extension outputs are included in the Supplement. Inundation datasets were obtained from http://wetlands.jpl.nasa.gov. The GLWD dataset was obtained from http://gcmd.gsfc.nasa.gov. The GLOBCOVER dataset was obtained from http://due.esrin.esa.int. The WDCGG data were obtained from http://ds.data.jma.go.jp/gmd/ wdcgg. The Surface WAter Microwave Product Series inundation dataset (described by Schroeder et al., 2015) was obtained from http://wetlands.jpl.nasa.gov (accessed on 5 June 2014); European Centre for Medium-Range Weather Forecasts reanalysis (ECMWF ERA-Interim) synoptic monthly means were downloaded from http: //apps.ecmwf.int. The code used to generate the FE and EE datasets is included in the Supplement. 


\section{Appendix A: CARDAMOM extension}

CARDAMOM heterotrophic respiration was derived from the Bloom et al. (2016) global terrestrial $\mathrm{C}$ cycle $1^{\circ} \times 1^{\circ}$ analysis. CARDAMOM-retrieved $\mathrm{C}$-state and process variables for the period 2001-2010 were used to run the ecosystem carbon balance model DALEC2 (Bloom and Williams, 2015) to span 2001-2015. The 2011-2015 ERA-Interim meteorological drivers and MODIS-burned area were obtained as described by Bloom et al. (2016). The CARDAMOM output consists of 4000 heterotrophic respiration realizations at each monthly time step; for each time step, we use the median CARDAMOM heterotrophic respiration output. We downscale the data to a $0.5^{\circ} \times 0.5^{\circ}$ resolution using a nearest neighbour interpolation.

\section{Appendix B: Error correlation structure}

We derive the model ensembles' space-time $n \times n$ error correlation matrix $\mathbf{M}$ as follows:

$M_{i j}=\operatorname{cor}\left(\boldsymbol{A}_{i, *}, \boldsymbol{A}_{j, *}\right)$,

where $n$ corresponds to the number of space and time wetland $\mathrm{CH}_{4}$ emission aggregations, and $i$ and $j$ span 1 to $n$. $A_{i, m}$ and $A_{j, m}$ correspond to the total $\mathrm{CH}_{4}$ flux for model $m$ within the $i$ th and $j$ th space-time aggregations (i.e. total wetland $\mathrm{CH}_{4}$ emissions within a given time and area); $\boldsymbol{A}_{i, *}$ and $\boldsymbol{A}_{j, *}$ are $1 \times N$ vectors, where $N$ is the number of models within the ensemble. The "cor()" operator denotes the Pearson's correlation coefficient between the two bracketed vectors. For Fig. 7, we aggregated model wetland $\mathrm{CH}_{4}$ emissions for each month across four zonal bands: boreal and Arctic $\left(>55^{\circ} \mathrm{N}\right)$ temperate $\left(23-55^{\circ} \mathrm{N}\right)$, tropical $\left(23-23^{\circ} \mathrm{N}\right)$ and Southern Hemisphere $\left(<23^{\circ} \mathrm{S}\right)$. A perfect correlation between the $i$ th and $j$ th indices $\left(M_{i j}=1\right)$ indicates that the models are consistently over- or under-predicting $\mathrm{CH}_{4}$ emissions at times-and-locations $i$ and $j$ relative to the ensemble mean; a perfect anti-correlation $\left(M_{i j}=-1\right)$ indicates that the models are consistently over-predicting $\mathrm{CH}_{4}$ emissions at time-and-location $i$ and consistently under-predicting $\mathrm{CH}_{4}$ emissions at time-and-location $j$ (relative to the ensemble mean) and vice versa.

\section{Appendix C: Dominant process uncertainty}

We quantify the dominant process uncertainty of wetland $\mathrm{CH}_{4}$ emission state variables ( $s=1-3$; (1) maximum emission month, (2) mean $\mathrm{CH}_{4}$ emissions and (3) seasonal variability in terms of standard deviation) to wetland emission controls $(e=1-3$; (1) model carbon decomposition, (2) $\mathrm{CH}_{4}: \mathrm{C}$ temperature dependence and (3) wetland extent parameterization) at location $x$ as follows:

$R_{x, s, e}=\sum_{c=1}^{N} \frac{\max \left(\boldsymbol{M}_{x, s, \boldsymbol{m}_{c}}\right)-\min \left(\boldsymbol{M}_{x, s, \boldsymbol{m}_{c}}\right)}{N}$,

where $R_{x, s, e}$ is the mean range of state variable $s$ across the ensemble given a fixed emission control $e$. $\boldsymbol{M}_{x, s, *}$ is a vector of all ensemble member state variables $s$ at location $x$, $\boldsymbol{m}_{c}$ denotes the indices of the ensemble subset driven by $c$ th emission control $e$, and $N$ values are the number of configurations for each $e$ (the ensemble configuration details are show in Table 1). The "max()" and "min()" functions denote the maximum and minimum elements of the bracketed vectors. For example, $R_{100,3,1}$ is the mean range of seasonal $\mathrm{CH}_{4}$ variability $(s=3)$ for a fixed carbon model configuration $(e=1)$ at the 100th grid cell $(x=100)$. We attribute the zonal dominant uncertainty of state variable $s$ to emission control $e$ as

$P_{z, s, e}=\frac{\sum_{x_{z}} r_{x_{z}, s, e} F_{x_{z}}}{\sum_{x_{z}} F_{x_{z}}} \times 100 \%$,

where $x_{z}$ values are the pixels $x$ within a $5^{\circ}$ zonal band $z, F_{x_{z}}$ is the mean 2009-2010 area-integrated $\mathrm{CH}_{4}$ flux (Eq. 1 in the main text) and $r_{x_{z}, s, e}=1$ if $R_{x_{z}, s, e}=\min \left(\boldsymbol{R}_{x_{z}, s, *}\right)$; otherwise, $r_{x_{z}, s, e}=0$. Therefore, $e$ is the largest source of uncertainty when the mean range in state variable $s$ is the smallest for a fixed $e . P_{z, s, e}$ denotes the percentage of zonal band $z$ where emission control $e$ is the greatest source of uncertainty for each $s$. 


\section{The Supplement related to this article is available online at https://doi.org/10.5194/gmd-10-2141-2017- supplement.}

Competing interests. The authors declare that they have no conflict of interest.

Acknowledgements. Part of this research was carried out at the Jet Propulsion Laboratory, California Institute of Technology, under a contract with the National Aeronautics and Space Administration. Funding for this study was provided through a NASA Carbon Monitoring System grant (\#NNH14ZDA001N-CMS). Funding for the Multi-scale synthesis and Terrestrial Model Intercomparison Project (MsTMIP; http://nacp.ornl.gov/MsTMIP.shtml) activity was provided through a NASA ROSES grant (\#NNX10AG01A). Data management support for preparing, documenting and distributing the model driver and output data was performed by the Modeling and Synthesis Thematic Data Center at Oak Ridge National Laboratory (ORNL; http://nacp.ornl.gov) with funding through a NASA ROSES grant (\#NNH10AN681). Finalized MsTMIP data products are archived at the ORNL DAAC (http://daac.ornl.gov)

Edited by: J. Williams

Reviewed by: two anonymous referees

\section{References}

Bastviken, D., Tranvik, L. J., Downing, J. A., Crill, P. M., and Enrich-Prast, A.: Freshwater methane emissions offset the continental carbon sink, Science, 331, p. 50, https://doi.org/10.1126/science.1196808, 2011.

Bey, I., Jacob, D. J., Yantosca, R. M., Logan, J. A., Field, B. D., Fiore, A. M., Li, Q., Liu, H. Y., Mickley, L. J., and Schultz, M. G.: Global modeling of tropospheric chemistry with assimilated meteorology: Model description and evaluation, J. Geophys. Res., 106, 23073-23096, https://doi.org/10.1029/2001JD000807, 2001.

Bloom, A. A. and Williams, M.: Constraining ecosystem carbon dynamics in a data-limited world: integrating ecological "common sense" in a model-data fusion framework, Biogeosciences, 12, 1299-1315, https://doi.org/10.5194/bg-12-1299-2015, 2015.

Bloom, A. A., Palmer, P. I., Fraser, A., Reay, D. S., and Frankenberg, C.: Large-Scale Controls of Methanogenesis Inferred from Methane and Gravity Spaceborne Data, Science, 327, 322-325, https://doi.org/10.1126/Science.1175176, 2010.

Bloom, A. A., Palmer, P. I., Fraser, A., and Reay, D. S.: Seasonal variability of tropical wetland $\mathrm{CH}_{4}$ emissions: the role of the methanogen-available carbon pool, Biogeosciences, 9, 28212830, https://doi.org/10.5194/bg-9-2821-2012, 2012.

Bloom, A. A., Exbrayat, J.-F., van der Velde, I. R., Feng, L., and Williams., M.: The decadal state of the terrestrial carbon cycle: Global retrievals of terrestrial carbon allocation, pools, and residence times, P. Natl. Acad. Sci. USA, 113, 1285-1290, https://doi.org/10.1073/pnas.1515160113, 2016.
Bloom, A. A., Bowman, K., Lee, M., Turner, A. J., Schroeder, R., Worden, J. R., Weidner, R. J., McDonald, K. C., and Jacob, D. J.: CMS: Global 0.5-deg Wetland Methane Emissions and Uncertainty (WetCHARTs v1.0). ORNL DAAC, Oak Ridge, Tennessee, USA, https://doi.org/10.3334/ORNLDAAC/1502, 2017.

Bontemps, S., Defourny, P., Bogaert, E. V., Arino, O., Kalogirou, V., and Perez, J. R.: Globcover Products Description and Validation Report, Tech. rep., ESA, 2011.

Bousquet, P., Ringeval, B., Pison, I., Dlugokencky, E. J., Brunke, E.G., Carouge, C., Chevallier, F., Fortems-Cheiney, A., Frankenberg, C., Hauglustaine, D. A., Krummel, P. B., Langenfelds, R L., Ramonet, M., Schmidt, M., Steele, L. P., Szopa, S., Yver, C., Viovy, N., and Ciais, P.: Source attribution of the changes in atmospheric methane for 2006-2008, Atmos. Chem. Phys., 11, 3689-3700, https://doi.org/10.5194/acp-11-3689-2011, 2011.

Bridgham, S. D., Cadillo-Quiroz, H., Keller, J. K., and Zhuang, Q.: Methane emissions from wetlands: biogeochemical, microbial, and modeling perspectives from local to global scales, Glob. Change Biol., 19, 1325-1346, https://doi.org/10.1111/gcb.12131, 2013.

Budishchev, A., Mi, Y., van Huissteden, J., Belelli-Marchesini, L., Schaepman-Strub, G., Parmentier, F. J. W., Fratini, G., Gallagher, A., Maximov, T. C., and Dolman, A. J.: Evaluation of a plotscale methane emission model using eddy covariance observations and footprint modelling, Biogeosciences, 11, 4651-4664, https://doi.org/10.5194/bg-11-4651-2014, 2014.

Butz, A., Guerlet, S., Hasekamp, O., Schepers, D., Galli, A., Aben, I., Frankenberg, C., Hartmann, J.-M., Tran, H., Kuze, A., Keppel-Aleks, G., Toon, G., Wunch, D., Wennberg, P., Deutscher, N., Griffith, D., Macatangay, R., Messerschmidt, J., Notholt, J., and Warneke, T.: Toward accurate $\mathrm{CO}_{2}$ and $\mathrm{CH}_{4}$ observations from GOSAT, Geophys. Res. Lett., 38, L14812, https://doi.org/10.1029/2011GL047888, 2011.

Chang, R. Y.-W., Miller, C. E., Dinardo, S. J., Karion, A., Sweeney, C. S., Daube, B. C., Henderson, J. M., Mountain, M. E.,Eluszkiewicz, J., Miller, J. B., Bruhwiler, L. M. P., and Wofsy, S. C.: Methane emissions from Alaska in 2012 from CARVE airborne observations, P. Natl. Acad. Sci. USA, 111, 16694-16699, https://doi.org/10.1073/pnas.1412953111, 2014.

Ciais, P., Sabine, C., Bala, G., Bopp, L., Brovkin, V., Canadell, J., Chhabra, A., DeFries, R., Galloway, J., Heimann, M., Jones, C., Le Quéré, C., Myneni, R. B., Piao, S., and Thornton, P.: Carbon and Other Biogeochemical Cycles, in: Climate Change 2013: The Physical Science Basis. Contribution of Working Group I to the Fifth Assessment Report of the Intergovernmental Panel on Climate Change, edited by: Stocker, T. F., Qin, D., Plattner, G.-K., Tignor, M., Allen, S. K., Boschung, J., Nauels, A., Xia, Y., Bex, V., and Midgley, P. M., Cambridge University Press, Cambridge, United Kingdom and New York, NY, USA, 1535 pp., 2013.

Entekhabi, D., Njoku, E. G., O’Neill, P. E., Kellogg, K. H., Crow, W. T., Edelstein, W. N., Entin, J. K., Goodman, S. D., Jackson, T. J., Johnson, J., and Kimball, J.: The soil moisture active passive (SMAP) mission, Proc. IEEE, 98, 704-716, https://doi.org/10.1109/JPROC.2010.2043918, 2010.

European Commission: Emission Database for Global Atmospheric Research (EDGAR), release version 4.2, Tech. rep., Joint Research Centre (JRC)/Netherlands Environmental Assessment 
Agency (PBL), available at: http://edgar.jrc.ec.europa.eu (last access: 1 December 2014), 2011.

Fluet-Chouinard, E., Lehner, B., Rebelo, L. M., Papa, F., and Hamilton, S. K.: Development of a global inundation map at high spatial resolution from topographic downscaling of coarse-scale remote sensing data, Remote Sens. Environ., 158, 348-361, https://doi.org/10.1016/j.rse.2014.10.015, 2015.

Fraser, A., Palmer, P. I., Feng, L., Boesch, H., Cogan, A., Parker, R., Dlugokencky, E. J., Fraser, P. J., Krummel, P. B., Langenfelds, R. L., O’Doherty, S., Prinn, R. G., Steele, L. P., van der Schoot, M., and Weiss, R. F.: Estimating regional methane surface fluxes: the relative importance of surface and GOSAT mole fraction measurements, Atmos. Chem. Phys., 13, 5697-5713, https://doi.org/10.5194/acp-13-5697-2013, 2013.

Fung, I., John, J., Lerner, J., Matthews, E., Prather, M., Steele, L. P., and Fraser, P. J.: Three-dimensional model synthesis of the global methane cycle, J. Geophys. Res., 96, 13033, https://doi.org/10.1029/91jd01247, 1991.

Glagolev, M., Kleptsova, I., Filippov, I., Maksyutov, S., and Machida, T.: Regional methane emission from West Siberia mire landscapes, Environ. Res. Lett., 6, 045214, https://doi.org/10.1088/1748-9326/6/4/045214, 2011.

Hodson, E. L., Poulter, B., Zimmermann, N. E., Prigent, C., and Kaplan, J. O.: The El Niño-Southern Oscillation and wetland methane interannual variability, Geophys. Res. Lett., 38, L08810, https://doi.org/10.1029/2011GL046861, 2011.

Holgerson, M. A. and Raymond, P. A.: Large contribution to inland water $\mathrm{CO}_{2}$ and $\mathrm{CH}_{4}$ emissions from very small ponds, Nat. Geosci., 9, 222-226, https://doi.org/10.1038/ngeo2654, 2016.

Huntzinger, D. N., Schwalm, C., Michalak, A. M., Schaefer, K., King, A. W., Wei, Y., Jacobson, A., Liu, S., Cook, R. B., Post, W. M., Berthier, G., Hayes, D., Huang, M., Ito, A., Lei, H., Lu, C., Mao, J., Peng, C. H., Peng, S., Poulter, B., Riccuito, D., Shi, X., Tian, H., Wang, W., Zeng, N., Zhao, F., and Zhu, Q.: The North American Carbon Program Multi-Scale Synthesis and Terrestrial Model Intercomparison Project - Part 1: Overview and experimental design, Geosci. Model Dev., 6, 2121-2133, https://doi.org/10.5194/gmd-6-2121-2013, 2013.

Huntzinger, D. N., Schwalm, C. R., Wei, Y., Cook, R. B., Michalak, A. M., Schaefer, K., Jacobson, A. R., Arain, M. A., Ciais, P., Fisher, J. B., Hayes, D. J., Huang, M., Huang, S., Ito, A., Jain, A. K., Lei, H., Lu, C., Maignan, F., Mao, J., Parazoo, N., Peng, C., Peng, S., Poulter, B., Ricciuto, D. M., Tian, H., Shi, X., Wang, W., Zeng, N., Zhao, F., and Zhu, Q.: NACP MsTMIP: Global 0.5-deg Terrestrial Biosphere Model Outputs (version 1) in Standard Format, Data set, available at: http://daac.ornl.gov, from Oak Ridge National Laboratory Distributed Active Archive Center, Oak Ridge, Tennessee, USA, https://doi.org/10.3334/ORNLDAAC/1225, 2016.

Jacob, D. J., Turner, A. J., Maasakkers, J. D., Sheng, J., Sun, K., Liu, X., Chance, K., Aben, I., McKeever, J., and Frankenberg, C.: Satellite observations of atmospheric methane and their value for quantifying methane emissions, Atmos. Chem. Phys., 16, 14371-14396, https://doi.org/10.5194/acp-16-143712016, 2016.

Kirschke, S., Bousquet, P., Ciais, P., Saunois, M., Canadell, J. G., Dlugokencky, E. J., Bergamaschi, P., Bergmann, D., Blake, D. R., Bruhwiler, L., Cameron-Smith, P., Castaldi, S., Chevallier, F., Feng, L., Fraser, A., Heimann, M., Hodson, E. L., Houwel- ing, S., Josse, B., Fraser, P. J., Krummel, P. B., Lamarque, J.F., Langenfelds, R. L., Le Quéré, C., Naik, V., O’Doherty, S., Palmer, P. I., Pison, I., Plummer, D., Poulter, B., Prinn, R. G., Rigby, M., Ringeval, B., Santini, M., Schmidt, M., Shindell, D. T., Simpson, I. J., Spahni, R., Steele, L. P., Strode, S. A., Sudo, K., Szopa, S., van der Werf, G. R., Voulgarakis, A., van Weele, M., Weiss, R. F., Williams, J. E., and Zeng, G.: Three decades of global methane sources and sinks, Nat. Geosci., 6, 813-823, https://doi.org/10.1038/ngeo1955, 2013.

Laanbroek, H. J.: Methane emission from natural wetlands: interplay between emergent macrophytes and soil microbial processes. A mini-review, Ann. Botany, 105, 141-153, https://doi.org/10.1093/aob/mcp201, 2010.

Lehner, B. and Döll, P.: Development and validation of a global database of lakes, reservoirs, and wetlands, J. Hydrol., 296, 122, https://doi.org/10.1016/j.jhydrol.2004.03.028, 2004.

Le Quéré, C., Andres, R. J., Boden, T., Conway, T., Houghton, R. A., House, J. I., Marland, G., Peters, G. P., van der Werf, G. R., Ahlström, A., Andrew, R. M., Bopp, L., Canadell, J. G., Ciais, P., Doney, S. C., Enright, C., Friedlingstein, P., Huntingford, C., Jain, A. K., Jourdain, C., Kato, E., Keeling, R. F., Klein Goldewijk, K., Levis, S., Levy, P., Lomas, M., Poulter, B., Raupach, M. R., Schwinger, J., Sitch, S., Stocker, B. D., Viovy, N., Zaehle, S., and Zeng, N.: The global carbon budget 1959-2011, Earth Syst. Sci. Data, 5, 165-185, https://doi.org/10.5194/essd-5-1652013, 2013.

Le Toan, T., Quegan, S., Davidson, M. W. J., Balzter, H., Paillou, P., Papathanassiou, K., Plummer, S., Rocca, F., Saatchi, S., Shugart, H., and Ulander, L.: The BIOMASS mission: Mapping global forest biomass to better understand the terrestrial carbon cycle, Remote Sens. Environ., 115, 2850-2860, https://doi.org/10.1016/j.rse.2011.03.020, 2011.

Liu, J., Bowman, K. W., Lee, M., Henze, D. K., Bousserez, N., Brix, H., Collatz, G. J., Menemenlis, D., Ott, L., Pawson, S., Jones, D., and Nassar, R.: Carbon monitoring system flux estimation and attribution: impact of ACOS-GOSAT XCO2 sampling on the inference of terrestrial biospheric sources and sinks, Tellus B, 66, 22486, https://doi.org/10.3402/tellusb.v66.22486, 2014.

Mahecha, M. D., Reichstein, M., Carvalhais, N., Lasslop, G., Lange, H., Seneviratne, S. I., Vargas, R., Ammann, C., Arain, M. A., Cescatti, A., Janssens, I. A., Migliavacca, M., Montagnani, L., and Richardson, A. D.: Global convergence in the temperature sensitivity of respiration at ecosystem level, Science, 329, 838-840, https://doi.org/10.1126/science.1189587, 2010.

Melack, J. M., Hess, L. L., Gastil, M., Forsberg, B. R., Hamilton, S. K., Lima, I. B. T., and Nova, E. M. L. M.: Regionalization of methane emissions in the Amazon basin with microwave remote sensing, Glob. Change Biol., 10, 530-544, 10.1111/j.13652486.2004.00763.x, 2004.

Melton, J. R., Wania, R., Hodson, E. L., Poulter, B., Ringeval, B., Spahni, R., Bohn, T., Avis, C. A., Beerling, D. J., Chen, G., Eliseev, A. V., Denisov, S. N., Hopcroft, P. O., Lettenmaier, D. P., Riley, W. J., Singarayer, J. S., Subin, Z. M., Tian, H., Zürcher, S., Brovkin, V., van Bodegom, P. M., Kleinen, T., Yu, Z. C., and Kaplan, J. O.: Present state of global wetland extent and wetland methane modelling: conclusions from a model intercomparison project (WETCHIMP), Biogeosciences, 10, 753788, https://doi.org/10.5194/bg-10-753-2013, 2013. 
Meng, L., Paudel, R., Hess, P. G. M., and Mahowald, N. M.: Seasonal and interannual variability in wetland methane emissions simulated by CLM4Me' and CAM-chem and comparisons to observations of concentrations, Biogeosciences, 12, 4029-4049, https://doi.org/10.5194/bg-12-4029-2015, 2015.

Michalak, A. M., Hirsch, A., Bruhwiler, L., Gurney, K. R., Peters, W., and Tans, P. P.: Maximum likelihood estimation of covariance parameters for Bayesian atmospheric trace gas surface flux inversions, J. Geophys. Res., 110, D24107, https://doi.org/10.1029/2005JD005970, 2005.

Miller, S. M., Miller, C. E., Commane, R., Chang, R. Y.-W., Dinardo, S. J., Henderson, J. M., Karion, A., Lindaas, J., Melton, J. R., Miller, J. B., Sweeney, C., Wofsy, S. C., and Michalak, A. M.: A multiyear estimate of methane fluxes in Alaska from CARVE atmospheric observations, Global Biogeochem. Cy., 30, 1441-1453, https://doi.org/10.1002/2016GB005419, 2016.

Miyajima, T., Wada, E., Hanba, Y. T., and Vijarnsorn, P.: Anaerobic mineralization of indigenous organic matters and methanogenesis in tropical wetland soils, Geochim. Cosmochim. Ac., 61, 3739-3751, https://doi.org/10.1016/S0016-7037(97)00189$0,1997$.

Myhre, G., Shindell, D., Bréon, F.-M., Collins, W., Fuglestvedt, J., Huang, J., Koch, D., Lamarque, J.-F., Lee, D., Mendoza, B., Nakajima, T., Robock, A., Stephens, G., Takemura, T., and Zhang, H.: Anthropogenic and Natural Radiative Forcing, in: Climate Change 2013: The Physical Science Basis. Contribution of Working Group I to the Fifth Assessment Report of the Intergovernmental Panel on Climate Change, edited by: Stocker, T. F., Qin, D., Plattner, G.-K., Tignor, M., Allen, S. K., Boschung, J., Nauels, A., Xia, Y., Bex, V., and Midgley, P. M., Cambridge University Press, Cambridge, United Kingdom and New York, NY, USA, 2013.

Nisbet, E. G., Dlugokencky, E. J., and Bousquet, P.: Methane on the Rise - Again, Science, 343, 493-495, https://doi.org/10.1126/science.1247828, 2014.

Olefeldt, D., Turetsky, M. R., Crill, P. M., and McGuire, A. D.: Environmental and physical controls on northern terrestrial methane emissions across permafrost zones, Glob. Change Biol., 19, 589-603, https://doi.org/10.1111/gcb.12071, 2013.

Parker, R., Boesch, H., Cogan, A., Fraser, A., Feng, L., Palmer, P. I., Messerschmidt, J., Deutscher, N., Griffith, D. W. T., Notholt, J., Wennberg, P. O., and Wunch, D.: Methane observations from the Greenhouse Gases Observing SATellite: Comparison to groundbased TCCON data and model calculations, Geophys. Res. Lett., 38, L15807, https://doi.org/10.1029/2011GL047871, 2011.

Pickett-Heaps, C. A., Jacob, D. J., Wecht, K. J., Kort, E. A., Wofsy, S. C., Diskin, G. S., Worthy, D. E. J., Kaplan, J. O., Bey, I., and Drevet, J.: Magnitude and seasonality of wetland methane emissions from the Hudson Bay Lowlands (Canada), Atmos. Chem. Phys., 11, 3773-3779, https://doi.org/10.5194/acp-113773-2011, 2011.

Pison, I., Ringeval, B., Bousquet, P., Prigent, C., and Papa, F.: Stable atmospheric methane in the 2000s: key-role of emissions from natural wetlands, Atmos. Chem. Phys., 13, 11609-11623, https://doi.org/10.5194/acp-13-11609-2013, 2013.

Riley, W. J., Subin, Z. M., Lawrence, D. M., Swenson, S. C., Torn, M. S., Meng, L., Mahowald, N. M., and Hess, P.: Barriers to predicting changes in global terrestrial methane fluxes: analyses using CLM4Me, a methane biogeochemistry model integrated in CESM, Biogeosciences, 8, 1925-1953, https://doi.org/10.5194/bg-8-1925-2011, 2011.

Saatchi, S. S., Harris, N. L., Brown, S., Lefsky, M., Mitchard, E. T., Salas, W., Zutta, B. R., Buermann, W., Lewis, S. L., Hagen, S., Petrova, S., White, L., Silman, M., and Morel, A.: Benchmark map of forest carbon stocks in tropical regions across three continents, P. Natl. Acad. Sci. USA, 108, 9899-9904, https://doi.org/10.1073/pnas.1019576108, 2011.

Saunois, M., Bousquet, P., Poulter, B., Peregon, A., Ciais, P., Canadell, J. G., Dlugokencky, E. J., Etiope, G., Bastviken, D., Houweling, S., Janssens-Maenhout, G., Tubiello, F. N., Castaldi, S., Jackson, R. B., Alexe, M., Arora, V. K., Beerling, D. J., Bergamaschi, P., Blake, D. R., Brailsford, G., Brovkin, V., Bruhwiler, L., Crevoisier, C., Crill, P., Covey, K., Curry, C., Frankenberg, C., Gedney, N., Höglund-Isaksson, L., Ishizawa, M., Ito, A., Joos, F., Kim, H.-S., Kleinen, T., Krummel, P., Lamarque, J.-F., Langenfelds, R., Locatelli, R., Machida, T., Maksyutov, S., McDonald, K. C., Marshall, J., Melton, J. R., Morino, I., Naik, V., O’ Doherty, S., Parmentier, F.-J. W., Patra, P. K., Peng, C., Peng, S., Peters, G. P., Pison, I., Prigent, C., Prinn, R., Ramonet, M., Riley, W. J., Saito, M., Santini, M., Schroeder, R., Simpson, I. J., Spahni, R., Steele, P., Takizawa, A., Thornton, B. F., Tian, H., Tohjima, Y., Viovy, N., Voulgarakis, A., van Weele, M., van der Werf, G. R., Weiss, R., Wiedinmyer, C., Wilton, D. J., Wiltshire, A., Worthy, D., Wunch, D., Xu, X., Yoshida, Y., Zhang, B., Zhang, Z., and Zhu, Q.: The global methane budget 2000-2012, Earth Syst. Sci. Data, 8, 697-751, https://doi.org/10.5194/essd-8-697-2016, 2016.

Schrier-Uijl, A.-P., Veraart, A. J., Leffelaar, P. A., Berendse, F., and Veenendaal, E. M.: Release of $\mathrm{CO}_{2}$ and $\mathrm{CH}_{4}$ from lakes and drainage ditches in temperate wetlands, Biogeochemistry, 102, 265-279, https://doi.org/10.1007/s10533-010-9440-7, 2011.

Schroeder, R., McDonald, K. C., Chapman, B. D., Jensen, K., Podest, E., Tessler, Z. D., Bohn, T. J., and Zimmermann, R.: Development and Evaluation of a Multi-Year Fractional Surface Water Data Set Derived from Active/Passive Microwave Remote Sensing Data, Remote Sensing, 7, 1668816732, https://doi.org/10.3390/rs71215843, 2015.

Singh, S., Kulshreshtha, K., and Agnihotri, S.: Seasonal dynamics of methane emission from wetlands, Chemosphere, 2, 39-46, https://doi.org/10.1016/S1465-9972(99)00046-X, 2000.

Sippel, S. J., Hamilton, S. K., Melack, J. M., and Choudhury, B. $\mathrm{J}$ : Determination of inundation area in the Amazon River floodplain using the SMMR $37 \mathrm{GHz}$ polarization difference, Remote Sens. Environ., 48, 70-76, https://doi.org/10.1016/00344257(94)90115-5, 1994.

Sjögersten, S., Black, C. R., Evers, S., Hoyos-Santillan, J., Wright, E. L., and Turner, B. L.: Tropical wetlands: A missing link in the global carbon cycle?, Global Biogeochem, Cy., 28, 1371-1386, https://doi.org/10.1002/2014GB004844, 2014.

Turetsky, M. R., Kotowska, A., Bubier, J., Dise, N. B., Crill, P., Hornibrook, E. R. C., Minkkinen, K., Moore, T. R., Myers-Smith, I. H., Nykänen, H., Olefeldt, D., Rinne, J., Saarnio, S., Shurpali, N., Tuittila, E.-S., Waddington, J. M., White, J. R., Wickland, K. P., and Wilmking, M.: A synthesis of methane emissions from 71 northern, temperate, and subtropical wetlands, Glob. Change Biol., 20, 2183-2197, https://doi.org/10.1111/gcb.12580, 2014. 
Turner, A. J., Jacob, D. J., Wecht, K. J., Maasakkers, J. D., Lundgren, E., Andrews, A. E., Biraud, S. C., Boesch, H., Bowman, K. W., Deutscher, N. M., Dubey, M. K., Griffith, D. W. T., Hase, F., Kuze, A., Notholt, J., Ohyama, H., Parker, R., Payne, V. H., Sussmann, R., Sweeney, C., Velazco, V. A., Warneke, T., Wennberg, P. O., and Wunch, D.: Estimating global and North American methane emissions with high spatial resolution using GOSAT satellite data, Atmos. Chem. Phys., 15, 7049-7069, https://doi.org/10.5194/acp-15-7049-2015, 2015.

van der Werf, G. R., Randerson, J. T., Giglio, L., Collatz, G. J., Mu, M., Kasibhatla, P. S., Morton, D. C., DeFries, R. S., Jin, Y., and van Leeuwen, T. T.: Global fire emissions and the contribution of deforestation, savanna, forest, agricultural, and peat fires (1997-2009), Atmos. Chem. Phys., 10, 11707-11735, https://doi.org/10.5194/acp-10-11707-2010, 2010.

Veefkind, J. P., Aben, I., McMullan, K., Forster, H., de Vries, J., Otter, G., Claas, J., Eskes, H. J., de Haan, J. F., Kleipool, Q., van Weele, M., Hasekamp, O., Hoogeveen, R., Landgraf, J., Snel, R., Tol, P., Ingmann, P., Voors, R., Kruizinga, B., Vink, R., Visser, H., and Levelt, P. F.: TROPOMI on the ESA Sentinel-5 Precursor: A GMES mission for global observations of the atmospheric composition for climate, air quality and ozone layer applications, Remote Sens. Environ., 120, 70-83, 2012.

Watts, J. D., Kimball, J. S., Bartsch, A., and McDonald, K. C.: Surface water inundation in the boreal-Arctic: potential impacts on regional methane emissions, Environ. Res. Lett., 9, 075001, https://doi.org/10.1088/1748-9326/9/7/075001, 2014.

Wecht, K. J., Jacob, D. J., Wofsy, S. C., Kort, E. A., Worden, J. R., Kulawik, S. S., Henze, D. K., Kopacz, M., and Payne, V. H.: Validation of TES methane with HIPPO aircraft observations: implications for inverse modeling of methane sources, Atmos. Chem. Phys., 12, 1823-1832, https://doi.org/10.5194/acp12-1823-2012, 2012.

Wecht, K. J., Jacob, D. J., Sulprizio, M. P., Santoni, G. W., Wofsy, S. C., Parker, R., Bösch, H., and Worden, J.: Spatially resolving methane emissions in California: constraints from the CalNex aircraft campaign and from present (GOSAT, TES) and future (TROPOMI, geostationary) satellite observations, Atmos. Chem. Phys., 14, 8173-8184, https://doi.org/10.5194/acp-148173-2014, 2014a.
Wecht, K. J., Jacob, D. J., Frankenberg, C., Jiang, Z., and Blake, D. R.: Mapping of North American methane emissions with high spatial resolution by inversion of SCIAMACHY satellite data, J. Geophys. Res.-Atmos., 119, 77417756, https://doi.org/10.1002/2014jd021551, 2014b.

Wei, Y., Liu, S., Huntzinger, D. N., Michalak, A. M., Viovy, N., Post, W. M., Schwalm, C. R., Schaefer, K., Jacobson, A. R., Lu, C., Tian, H., Ricciuto, D. M., Cook, R. B., Mao, J., and Shi, X.: The North American Carbon Program Multi-scale Synthesis and Terrestrial Model Intercomparison Project - Part 2: Environmental driver data, Geosci. Model Dev., 7, 2875-2893, https://doi.org/10.5194/gmd-7-2875-2014, 2014.

Wik, M., Thornton, B. F., Bastviken, D., Uhlback, J., and Crill, P. M.: Biased sampling of methane release from northern lakes: A problem for extrapolation, Geophys. Res. Lett., 43, 1256-1262, https://doi.org/10.1002/2015GL066501, 2016.

Wilson, C., Gloor, M., Gatti, L. V., Miller, J. B., Monks, S. A., McNorton, J., Bloom, A. A., Basso, L. S., and Chipperfield, M. P.: Contribution of regional sources to atmospheric methane over the Amazon Basin in 2010 and 2011, Global Biogeochem. Cy., 30, 400-420, https://doi.org/10.1002/2015GB005300, 2016.

Yvon-Durocher, G., Allen, A. P., Bastviken, D., Conrad, R., Gudasz, C., St-Pierre, A., Thanh-Duc, N., and del Giorgio, P. A.: Methane fluxes show consistent temperature dependence across microbial to ecosystem scales, Nature, 507, 488-491, https://doi.org/10.1038/nature13164, 2014. 